\title{
Review of the Fishes of the Genus Kublia (Perciformes: Kuhliidae) of the Central Pacific ${ }^{1}$
}

\author{
Jobn E. Randall and Helen A. Randall ${ }^{2}$
}

\begin{abstract}
Ten species of fishes of the genus Kublia are recognized from Palau to Hawai' $i$ in the North Pacific and from Fiji to Easter Island in the South Pacific: $K$ malo (Valenciennes) from fresh water in the Society Islands; $K$. marginata (Cuvier) from fresh water in the western Pacific, east to Kosrae, Caroline Islands, and Fiji; $K$. mugil (Forster) ( $K$. taeniura is a synonym) from most of the Indo-Pacific (not the Hawaiian Islands) and the tropical eastern Pacific; $K$. munda (De Vis) from fresh and brackish water in Fiji, Vanuatu, New Caledonia, and Queensland ( $K$. proxima Kendall \& Goldsborough and $K$. bilunulata Herre are synonyms); K. nutabunda Kendall \& Radcliffe from Easter Island; $K$. petiti Schultz from the Phoenix Islands, Malden Island, and the Marquesas Islands (Dules taeniurus marquesensis Fowler is a synonym); $K$. sandvicensis (Steindachner) from the Hawaiian Islands and other islands of the central Pacific; K. rupestris (Lacépède) from fresh water from East Africa to Samoa ( $K$. caerulescens Regan from the Solomon Islands is a new synonym); $K$. salelea Schultz from fresh water in the Samoa Islands; and K. xenura (Jordan \& Gilbert) from the Hawaiian Islands, with a mistaken type locality of El Salvador, Central America. The name $K$. sandvicensis has long been used for the common endemic species in the Hawaiian Islands; however, the original description leaves little doubt that it should apply to the species widely distributed in the central Pacific and only recently discovered in Hawai $i$; it has usually been misidentified as $K$. marginata. The endemic Hawaiian species therefore takes the only available name, K. xenura (Jordan \& Gilbert). Kublia sandvicensis differs from K. xenura in having a smaller eye (3.0-3.45 in head length, compared with 2.55-2.95 for $K$. xenura), straight dorsal profile of the head of adults (concave in xenura); usually 14 pectoral-fin rays (usually 15 in xenura), usually 50 lateral-line scales (usually 49 in xenura), gill rakers 38-43 (35-39 for xenura), and a dark reticular pattern dorsally on the head in life.
\end{abstract}

The Fishes of the family Kuhliidae are moderately deep-bodied and compressed, with two opercular spines, a deeply notched dorsal fin of 10 spines and $9-13$ rays, and a scaly sheath at the base of the dorsal and anal fins. They have large eyes and are primarily nocturnal, at least as adults, feeding princi-

${ }^{1}$ Manuscript accepted 12 November 2000.

2 Bishop Museum, 1525 Bernice Street, Honolulu, Hawaici 96817-2704.

Pacific Science (2001), vol. 55, no. 3:227-256

(C) 2001 by University of Hawai'i Press

All rights reserved pally on planktonic crustaceans. These fishes are generally silvery, often with dark markings on the caudal fin, the basis for the common name flagtails. The Hawaiian name aholehole is also sometimes used beyond Hawai'i. The family consists of a single genus, Kublia, the species of which occur in tropical and subtropical waters of the IndoPacific region, and one is also found in the tropical eastern Pacific. Only one species exceeds $320 \mathrm{~mm}$ in total length. Some species occur mainly in fresh water, whereas others are primarily marine. The latter tend to form schools by day and are typically found inshore; the young may be common in tide pools. At least some of the marine species are 
able to live in fresh water, and the freshwater species often occur in brackish environments.

In total 40 nominal species and subspecies of Kublia have been described (Eschmeyer 1998:2343), 18 of these in the genus Dules, now determined as a genus of Serranidae. Kublia was revised by Regan (1913), who recognized 12 species, three of which he described as new. Six species and subspecies of the genus have been described since 1913 .

A second species of Kublia was recently discovered in the Hawaiian Islands. It is the fish currently identified as Kublia marginata (Cuvier), described from Java and presumed to be wide-ranging throughout much of Oceania, including Johnston Island. We examined the holotype of Dules marginatus in the Muséum National d'Histoire Naturelle in Paris (MNHN 9002, $93 \mathrm{~mm}$ SL, not the "syntypes" listed by Eschmeyer [1998:1019]; Cuvier described the species from a single specimen). The holotype has 13 pectoral rays, 41 lateral-line scales, and $7+17$ gill rakers. None of these counts matches those of the fish of Pacific islands now identified as Kublia marginata. We first suspected that this new record of Kublia for Hawai'i represented an undescribed species, in spite of its broad distribution. We referred to the original description of Kublia sandvicensis (Steindachner, 1876) to make sure it applied to the common endemic Hawaiian species that has long held this name. To our dismay, we found that it fits the other species. The only available name for the endemic Hawaiian species of Kublia is K. xenura (Jordan \& Gilbert, 1882), originally named Xenicbthys xenurus and mistakenly placed in the Haemulidae. The questioned type locality of El Salvador is clearly in error.

Hombron and Jacquinot (1853) reported on fishes collected during Dumont d'Urville's voyage to the South Pole by the corvettes "Astrolabe" and "Zélée," 1837-1840. Among the species briefly described and without meristic data was Dules marginata Cuvier, illustrated as fig. 3 on Plate 3. Boulenger (1895:38) redescribed this fish as Dules urvillii and gave the locality as "Probably some $\mathrm{Pa}$ cific Island." No type specimen is extant, and we cannot equate this description with any species of Kublia we know today. The strong black markings of the caudal fin suggest that it may have been one of the freshwater species of the genus. Apogon aroubiensis is another species described and illustrated in Hombron and Jacquinot that is regarded as unidentifiable (Randall and Lachner 1986).

We recognize 10 species of the genus Kublia from the islands of Oceania. Of these, only $K$. mugil and $K$. rupestris range to the western Indian Ocean. We provide here a key to the species of Kublia from the islands of Oceania, illustrations, and a diagnosis of each. Not included in our study are the nominal $K$. boninensis (Fowler) from the western Pacific, $K$ caudovittata (Lacépède) from Madagascar and Mauritius, K. sauvagii Regan from Madagascar, and K. splendens Regan from fresh water at Rodriguez and Mauritius.

\section{MATERIALS AND METHODS}

Specimens of Kublia have been examined at or obtained on loan from the Australian Museum, Sydney (ams); Academy of Natural Sciences of Philadelphia (ANSP); the Natural History Museum, London (вмNн); Bernice P. Bishop Museum, Honolulu (вРвм); California Academy of Sciences, San Francisco (CAs); Hebrew University, Jerusalem (HUJ); Natural History Museum of Los Angeles County (LACM); Muséum National d'Histoire $\mathrm{Na}$ turelle, Paris (MNHN); Royal Ontario $\mathrm{Mu}-$ seum, Toronto (вом); and the National Museum of Natural History, Washington, D.C. (USNM).

Lengths given for specimens are standard length (SL), the straight-line distance from the median anterior point of upper lip to the base of the caudal fin (posterior end of the hypural plate). Head length is measured from the same anterior point to the most posterior end of the opercular membrane, and snout length from the same point to the fleshy edge of the orbit. Body depth is the greatest depth measured to the base of the dorsal spines; body width is the greatest width just posterior to the gill opening. Orbit diameter is the greatest fleshy diameter. The bony inter- 
orbital width is measured over the center of the eye. Caudal-peduncle depth is the least depth, and caudal-peduncle length is measured horizontally from the rear base of the anal fin to the caudal-fin base. Lengths of fin spines and soft rays are taken from the tips to where they emerge from the basal scaly sheath (these lengths may be taken more accurately than ones to the extreme base of the spines and rays). Caudal concavity is the horizontal distance between verticals at the tips of the shortest and longest caudal rays.

Pectoral-ray counts include the short unbranched upper ray (but not the still smaller splintlike ray that is closely joined to it). Lateral-line scales are counted from the upper end of the gill opening to the base of the caudal fin (four to seven pored scales on the base of the caudal fin are not counted, but a pored scale overlapping the end of the hypural plate is included). Gill-raker counts include rudiments; the upper-limb count is given first, and the raker at the angle is contained in the lower-limb count. As noted by Schultz (1943:99) and Gosline (1955:472), the young of Kublia have fewer gill rakers than adults. This may be due to rudimentary rakers being more difficult to detect in juveniles rather than an actual increase in rakers with growth. Nevertheless, in this study, no gill-raker counts were recorded for specimens less than $70 \mathrm{~mm}$ SL.

Tables 1-3 present the meristic data of all 10 species. Proportional measurements were taken only on specimens $80 \mathrm{~mm}$ SL or larger. Body and fin proportions in the text are rounded to the nearest 0.05 .

\section{Genus Kublia Gill}

Kublia Gill, 1861:48 (type species, Perca ciliata Cuvier in Cuvier and Valenciennes (after Kuhl and van Hasselt), $1828=$ Centropomus rupestris Lacépède, 1802, by original designation).

Moronopsis Gill, 1864:82 (type species, Dules marginatus Cuvier in Cuvier and Valenciennes, 1829 , by monotypy).

Herops De Vis, 1884:392 (type species, Herops munda De Vis, by monotypy).
Boulengerina Fowler, 1907:512 (type species, Dules mato Lesson, 1831; proposed as a subgenus; preoccupied by Boulengerina Dollo, 1886, in Reptilia).

Safole Jordan, 1912:655 (replacement name for Boulengerina Fowler).

Diagnosis: Dorsal-fin rays $\mathrm{X}, 9-13$, the fin deeply notched; anal-fin rays III, 10-13; pectoral-fin rays 13-15; pelvic rays I,5; lateral line complete, the pored scales 39-53; gill rakers long and slender, $7-13+16-30$; branchiostegal rays 6 ; gill membranes not joined across isthmus; vertebrae 25; body moderately deep, the depth $2.55-3.1$ in SL, and compressed; head moderately pointed, its length 3.0-3.6 in SL; mouth protractile, oblique with lower jaw projecting, and moderately large, the maxilla extending to below eye; supramaxilla not present; teeth villiform in jaws, on vomer, palatines, entopterygoids, and ectopterygoids; opercle with two spines; rounded corner and lower edge of preopercle finely serrate; edge of preorbital more coarsely serrate (serrae may be obsolete in large specimens); a few small serrae often present on edge of suborbital; scales ctenoid, present on cheek and opercle, none on interorbital, snout, or maxilla; dorsal and anal fins with a basal scaly sheath; no scaly pelvicaxillary process; caudal fin emarginate to deeply forked. Color silvery, a few species with small dark spots on body, the caudal fin often with black markings. One species reported to $400 \mathrm{~mm}$ total length, the remaining less than $320 \mathrm{~mm}$.

REMARKs: Platysome was described by Liénard (1832) as a new genus, type species Holocentrus caudavittata Lacépède, hence an earlier name than Kublia. Scudder (1882:268) latinized it to Platysoma, but that name is preoccupied. Maugé in Daget et al. (1986) regarded Platysome as invalid. Eschmeyer (1998: 2080) wrote, "the type was not definitely referred and the description inadequate." In any case, the well-established Kublia can be conserved on the grounds that Platysome has not been used as a valid genus since it was proposed (International Code of Zoological Nomenclature 2000). 


\section{KEY TO THE SPECIES OF Kublia FROM THE ISLANDS OF OCEANIA \\ (MICRONESIA, POLYNESIA, AND FIJI)}

la. Lateral-line scales 39-42; preorbital serrae 18-31 (except rupestris) ..................

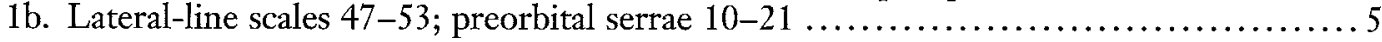

2a. Caudal fin emarginate, the caudal concavity 5.3-8.7 in head length; anal soft rays 10-11 (rarely 11); mouth large, the maxilla ending below posterior half of eye; edges of scales on body black or with a black bar or spot; juveniles with a large black spot in each lobe of caudal fin, and anteriorly in soft portion of dorsal fin, spreading to cover most of these fins in adults (East Africa to Samoa, in fresh water)............ rupestris

2b. Caudal fin forked, the caudal concavity $1.55-3.8$ in head length; anal soft rays 11-13; mouth not as large, the maxilla ending below anterior half of eye (usually below anterior fourth); posterior border of caudal fin and outer anterior part of soft dorsal

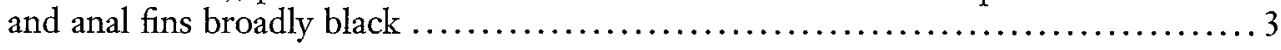

3a. Lower-limb gill rakers $16-19$; total gill rakers $23-28$; pectoral-fin rays 13 (western Pacific east to Caroline Islands, in fresh water) ......................marginata

3b. Lower-limb gill rakers 20-26; total gill rakers $30-35$; pectoral-fin rays usually $14 \ldots \ldots .4$

4a. Lower-limb gill rakers 20-22; total gill rakers 28-32; caudal concavity 3.0-3.8 in head length (Society Islands, in fresh water) .............................. malo

4b. Lower-limb gill rakers 24-26; total gill rakers 33-35; caudal concavity $2.5-2.7$ in head length (Samoa Islands, in fresh water) ................................. salelea

5a. Caudal fin with a median black stripe and two broad oblique black bands across each lobe; dorsal soft rays usually 10 (Indo-Pacific and tropical eastern Pacific)...... mugil

5 b. Caudal fin without black bands as in 5a; dorsal soft rays usually 11 (rarely 10)........6

6a. Caudal fin with base and all of margins broadly black, the chevron-shaped central part pale (yellow in life); lateral-line scales 47-49; preorbital serrae 14-21 (Fiji, Vanuatu, New Caledonia, and Queensland in brackish and fresh water)................ munda

6b. Caudal fin not colored as in 6a; lateral-line scales 49-53; preorbital serrae 10-15

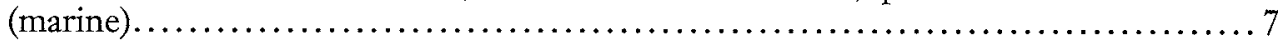

7a. Caudal fin black with a large C-shaped white mark basally in each lobe, the lobe tips white; anal soft rays usually 12; lateral-line scales 51-53; upper-limb gill rakers 9-11; total gill rakers 34-38 (Phoenix Islands, Malden Island, and Marquesas Islands)................................................... petiti

7b. Caudal fin not colored as in 7a, the posterior border entirely blackish; anal soft rays usually 11; lateral-line scales 49-51 (modally 49 or 50); upper-limb gill rakers 9-13;

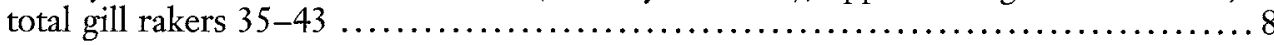

8a. Eye not very large, the orbit diameter 3.0-3.45 in head length; dorsal profile of head of adults straight; lower-limb gill rakers 27-30; total gill rakers 38-43; a dark reticular pattern dorsally on head in life (islands of central Pacific, including

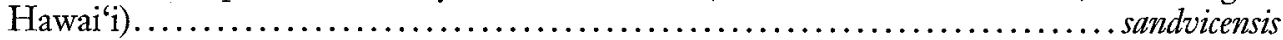

8b. Eye very large, the orbit diameter $2.55-2.95$ in head length; dorsal profile of head of adults concave; lower-limb gill rakers 25-28; total gill rakers 35-39; no dark

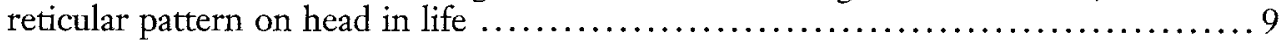

9a. Pectoral-fin rays usually 15 (11 of 55 with 14); lateral-line scales usually 49 (22 of 55 with 50, one with 51 ); pelvic spine $2.2-2.5$ in head length; second anal spine $86-98 \%$ length of third anal spine (Hawaiian Islands) ................... xenura 


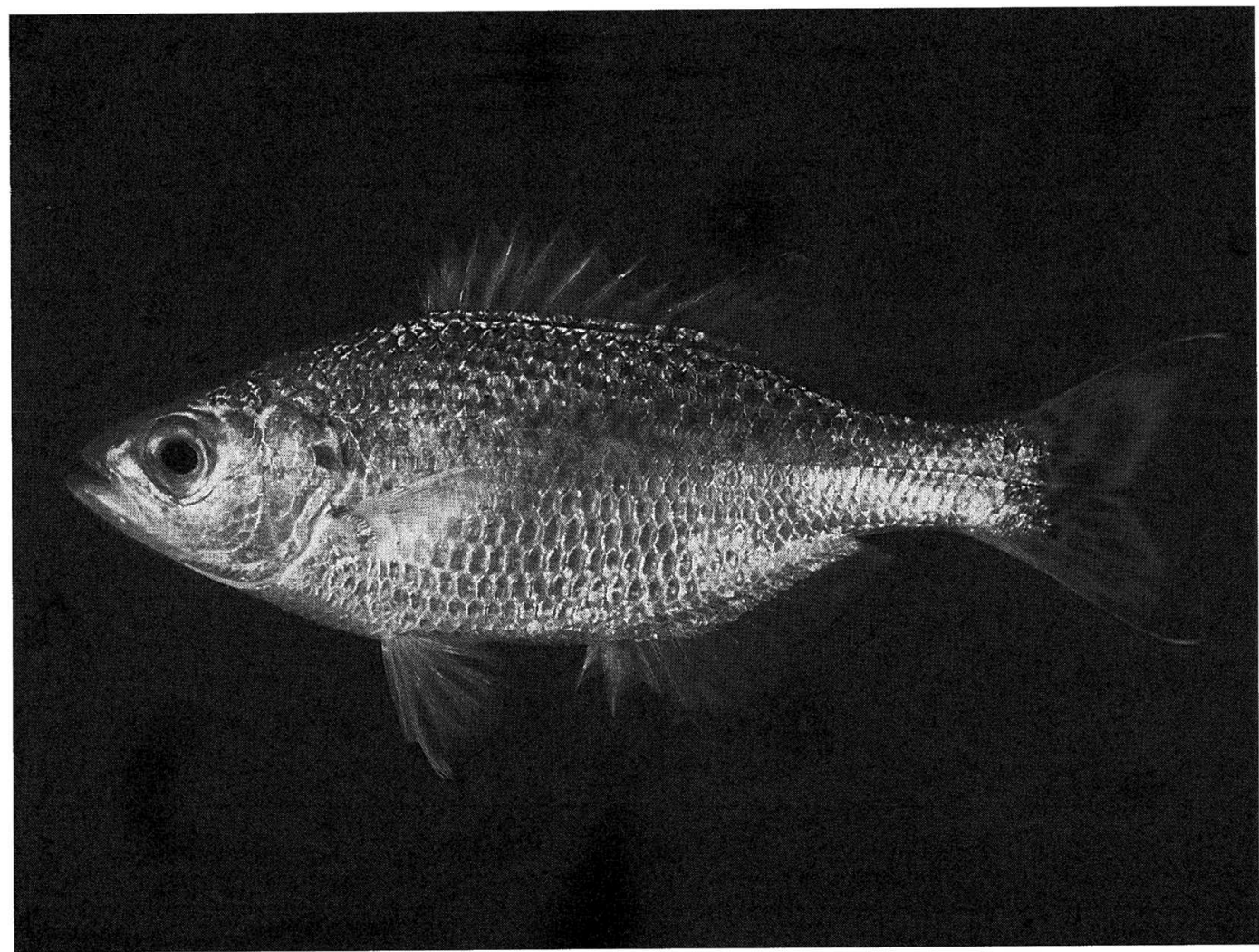

Figure 1. Kuhlia malo, врвм 11959, $128 \mathrm{~mm}$ SL, Moorea, Society Islands.

9b. Pectoral-fin rays 14 (one of 18 with 15); lateral-line scales usually 50 (4 of 19 with 49); pelvic spine $2.5-2.9$ in head length; second anal spine $73-87 \%$ length of third

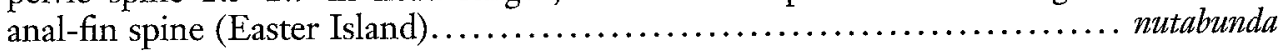

\section{Kublia malo (Valenciennes)}

Figure 1; Tables 1-3

Dules malo Valenciennes in Cuvier and Valenciennes, 1831:475 (type locality, Matavai River, Tahiti).

Dules mato Lesson, 1831:223 (type locality, Matavai, Tahiti).

Dules leuciscus Jenyns, 1840:17 (type locality, Matavai River, Tahiti).

Kublia marginata (non Cuvier), Herre, 1936:145 (Papenoo River, Tahiti, and creek on Moorea).

DIAGNosis: Dorsal-fin rays $\mathrm{X}, 11-12$ (usually 11); anal-fin rays $\mathrm{III}, 11-13$ (usually
12); pectoral-fin rays $13-14$ (usually 14); lateral-line scales $40-42$; gill rakers $8-10+$ 20-22; preorbital serrae 22-31; body depth 2.7-3.1 in SL; maxilla reaching to or beyond a vertical at front edge of pupil, but not beyond center of eye; caudal fin slightly forked, the caudal concavity 3.0-3.8 in head length. Color silvery with small, round, black spots dorsally on body; posterior edge and lobe tips of caudal fin broadly black, the upper and lower edges of lobes narrowly pale; pale central part of caudal fin with blackish streaks and elongate spots that parallel the rays. Largest specimen examined, $137 \mathrm{~mm}$ SL.

REMARKS: Fowler $(1928: 169)$ wrote that the first use of the name Dules malo was by 
TABLE 1

Counts of Soft Fin Rays of Central Pacific Species of Kublia

\begin{tabular}{|c|c|c|c|c|c|c|c|c|c|c|}
\hline \multirow[b]{2}{*}{ Species } & \multicolumn{3}{|c|}{ Dorsal Rays } & \multicolumn{4}{|c|}{ Anal Rays } & \multicolumn{3}{|c|}{ Pectoral Rays } \\
\hline & 10 & 11 & 12 & 10 & 11 & 12 & 13 & 13 & 14 & 15 \\
\hline malo & & 18 & 5 & & 1 & 21 & 1 & 4 & 19 & \\
\hline marginata & 3 & 35 & 1 & & 27 & 12 & & 27 & 12 & \\
\hline mugil & 19 & 11 & & 3 & 26 & 1 & & 4 & 25 & 1 \\
\hline munda & 1 & 18 & & & 19 & & & 3 & 16 & \\
\hline nutabunda & & 18 & & 1 & 17 & & & & 17 & 1 \\
\hline petiti & 1 & 22 & 4 & & 2 & 25 & & 1 & 25 & 1 \\
\hline mupestris & 3 & 19 & & 20 & 2 & & & 4 & 18 & \\
\hline salelea & & 12 & & & 6 & 6 & & & 12 & \\
\hline sandvicensis & & 56 & 1 & & 56 & 1 & & 4 & 52 & 1 \\
\hline xemura & & 53 & 2 & 3 & 52 & & & & 11 & 44 \\
\hline
\end{tabular}

Cuvier in the second edition of Règne Animal (1829:147), adding that it is a nomen nudum; however, we do not find this name in our copy of the volume.

The Tahitian name for this fish is nato, hence the basis for Lesson's name mato and the emendation by Valenciennes to malo. Although the date of publication of Lesson is often given as 1830, Jordan and Jordan $(1922: 41)$ noted that Lesson quoted Cuvier and Valenciennes (1831) with the correct page; therefore, this part of Lesson's publication must have appeared after volume 7 of Cuvier and Valenciennes, and Dules mato Lesson is a junior synonym.

We have examined specimens of Kublia malo only from streams and rivers in Tahiti and Moorea. It should be expected to occur naturally in fresh water at other high islands of French Polynesia except the Marquesas.

The Division of Fish and Game of the State of Hawai'i decided to transport nato (Kublia malo) from Tahiti to the Hawaiian Islands aboard the National Marine Fisheries Service vessel Hugb M. Smith for introduction to freshwater habitats. For this privilege, the French Government asked that some nato be transported to and released in fresh water in the Marquesas. In 1958, 1868 fish were collected from a stream in Tautira, Tahiti, and placed in the saltwater bait tank on the vessel. Only 94 survived the trip to Nuku
Hiva; 50 were planted in Taipi Vai. The remaining 44 died enroute to Hawai' $i$, which was fortunate (Randall 1960). Had the nato been successfully introduced, it would surely have had a deleterious effect on the native freshwater biota of Hawai'i.

Bryan and Herre (1903:129) erroneously recorded this fish from Marcus Island (= Minami Tori Shima) as Kublia marginata. This island has no surface fresh water, and it is far from the Society Islands, the only known locality for $K$. malo. The next species listed from Minami Tori Shima by Bryan and Herre, Epinepbelus spiniger (=E. irroratus) is also an error; it is endemic to the Marquesas Islands. Because Alvin Seale's collections from the South Pacific in 1900-1903, which included specimens from Tahiti and the Marquesas (Seale 1906), would have been at the Bishop Museum at the same time as Bryan's collections, we believe that his specimens of these two fishes were mistakenly recorded as being from Minami Tori Shima.

MATERIAL EXAMINED: SOCIETY ISLANDS, Tahiti, ANSP 16008, 3: 48.5-87 mm; ANSP 105268, $77.5 \mathrm{~mm}$; вРBM 1534, $137 \mathrm{~mm}$; врвм 2417, $128 \mathrm{~mm}$ (locality given as Marcus Island, but probably Tahiti); врвм 3921, 2: 68-82 $\mathrm{mm}$; вРвм 7202, 4: 73-80 mm. Moorea, врвм 11959, $128 \mathrm{~mm}$; вРвм 25754, 4: 99-132 mm; CAS 124712 , 6: 19-111 mm. 


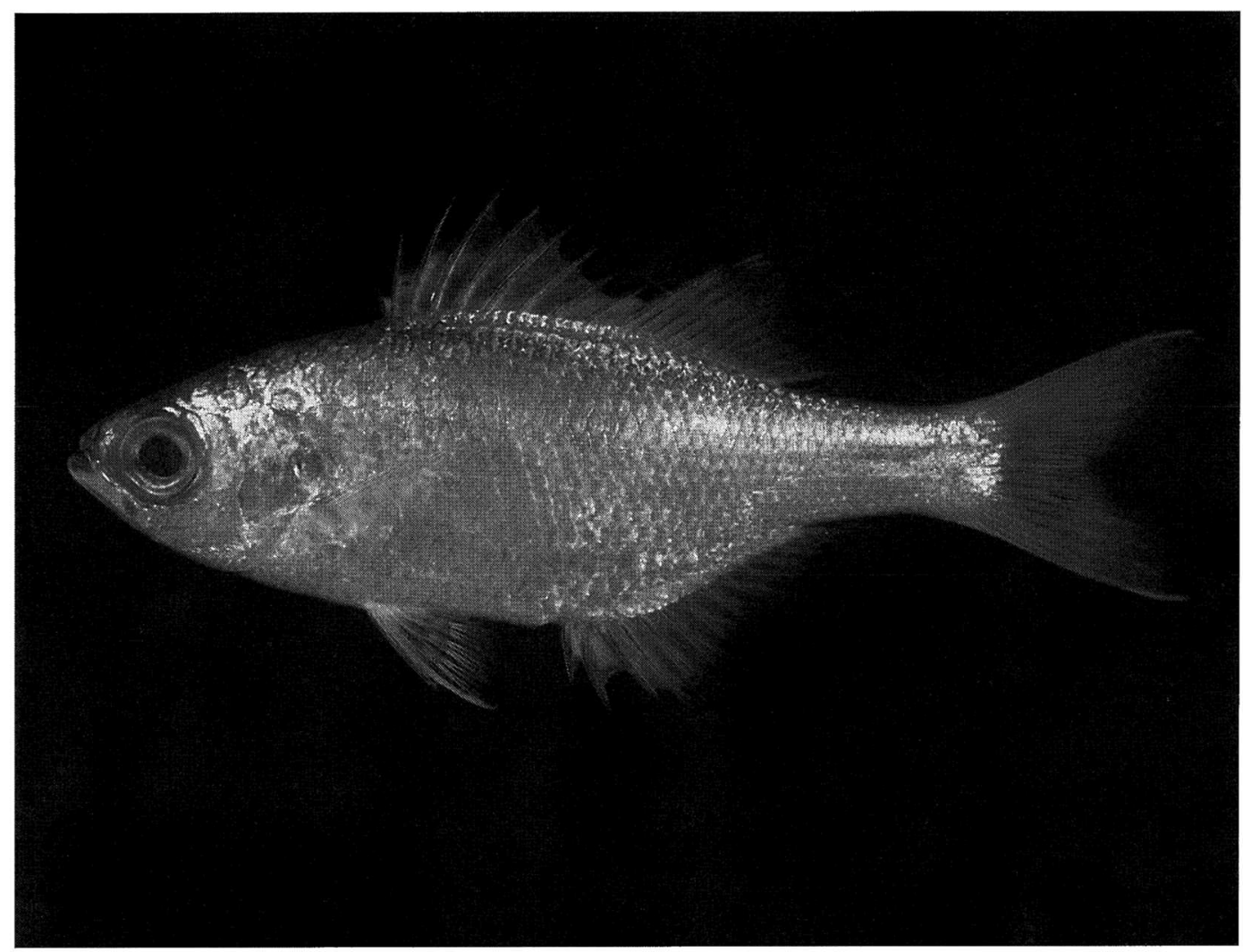

Figure 2. Kublia marginata, вPBм 26618, 93 mm SL, Sulawesi, Indonesia.

Kublia marginata (Cuvier)

Figures 2, 3; Tables $1-3$

Dules marginatus Cuvier in Cuvier and $\mathrm{Va}$ lenciennes, 1829:116, pl. 52 (type locality, Java).

Dules maculatus Valenciennes in Cuvier and Valenciennes, 1831:475 (type locality, Sulawesi).

Dules papuensis Macleay, 1884:257 (type locality, Goldie River, Papua New Guinea).

DiAgnosis: Dorsal-fin rays $\mathrm{X}, 10-12$ (usually 11); anal-fin rays III, 11 or 12 (usually 11); pectoral-fin rays 13 or 14 (usually 13 ); lateral-line scales 39-42; gill rakers 7-9+ 16-19; preorbital serrae 18-28; a few fine serrae may be present on suborbital; body depth 2.7-3.05 in SL; orbit diameter 2.75-
3.3 in head length; maxilla extending to or slightly beyond a vertical at front edge of pupil; caudal fin forked, the caudal concavity 2.5-3.1 in head length. Silvery, usually with blackish spots posteriorly on dorsal part of body that tend to merge to form bands anteriorly (or the dark pigment is concentrated on scale margins); most of snout and tip of chin blackish; caudal fin pale with a black posterior margin that broadens on lobe tips, then a very broad submarginal pale zone, often preceded by a chevron-shaped blackish band or row of blackish spots parallel with posterior margin; base of caudal fin with small blackish spots; a narrow white margin on soft portion of dorsal and anal fins with a broad blackish submarginal zone anteriorly that narrows posteriorly (broader in dorsal fin than anal). Largest specimen examined, $179 \mathrm{~mm} \mathrm{SL}$, from the Solomon Islands. 


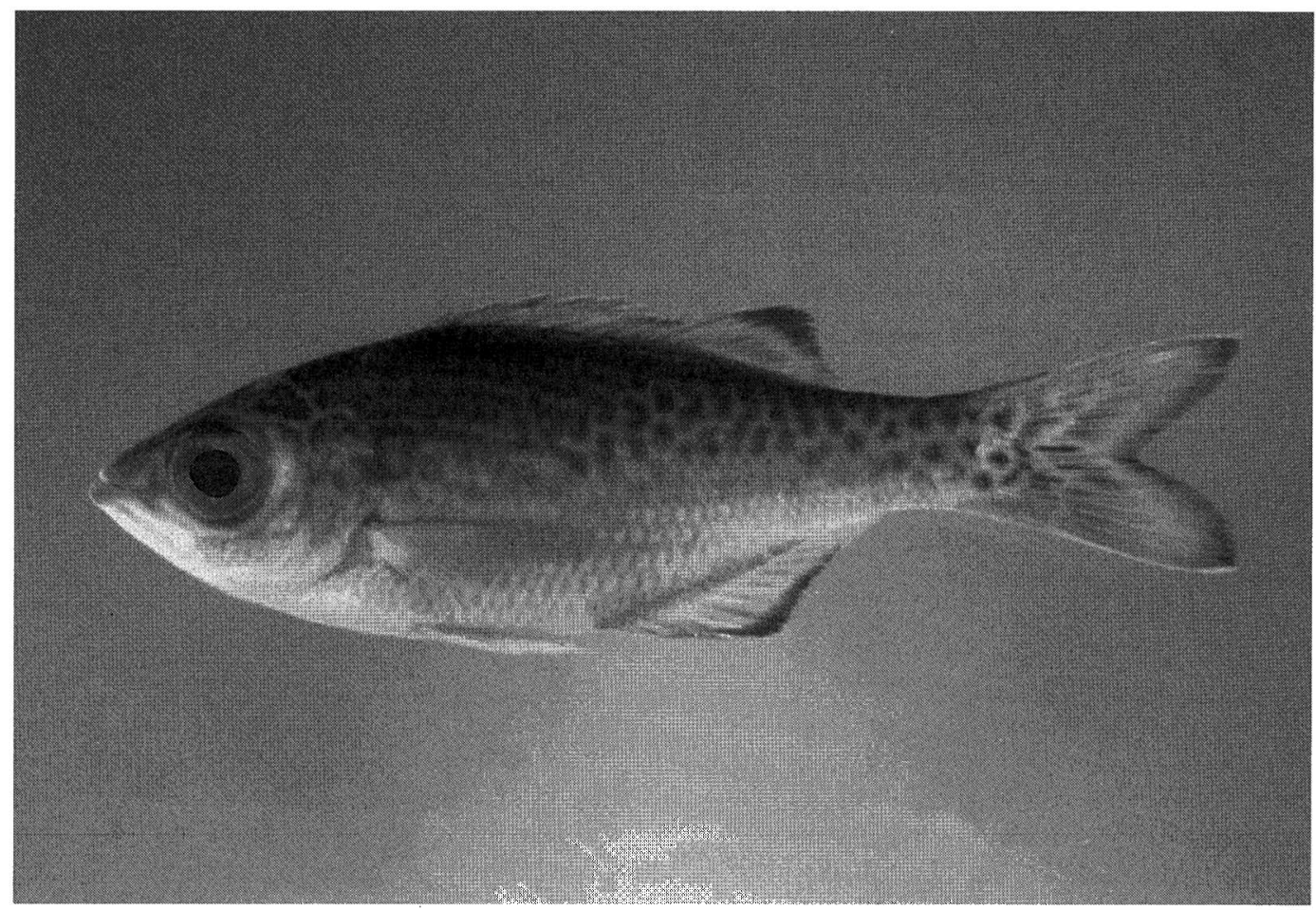

Figure 3. Kublia marginata, MNHN 1992-619, 96 mm SL, New Caledonia.

TABLE 2

Lateral-Line Scale Counts of Central Pacific Species of Kublia

\begin{tabular}{|c|c|c|c|c|c|c|c|c|c|c|c|c|c|c|c|}
\hline \multirow[b]{2}{*}{ Species } & \multicolumn{15}{|c|}{ Lateral-Line Scales } \\
\hline & 39 & 40 & 41 & 42 & 43 & 44 & 45 & 46 & 47 & 48 & 49 & 50 & 51 & 52 & 53 \\
\hline malo & & 6 & 12 & 5 & & & & & & & & & & & \\
\hline marginata & 5 & 18 & 12 & 4 & & & & & & & & & & & \\
\hline mugil & & & & & & & & & & & 2 & 7 & 20 & 1 & \\
\hline munda & & & & & & & & & 1 & 6 & 12 & & & & \\
\hline nutabunda & & & & & & & & & & & 4 & 15 & & & \\
\hline petiti & & & & & & & & & & & & & 25 & 5 & 1 \\
\hline rupestris & 6 & 9 & 7 & & & & & & & & & & & & \\
\hline salelea & & 3 & 6 & 3 & & & & & & & & & & & \\
\hline sandvicensis & & & & & & & & & & & 1 & 39 & 17 & & \\
\hline xenura & & & & & & & & & & & 32 & 22 & 1 & & \\
\hline
\end{tabular}

REMARKS: Kublia marginata is primarily a freshwater fish. The 101- $\mathrm{mm}$ specimen of $\mathrm{CAS}$ 125575 was collected from the Sepik River, Papua New Guinea, at Marienberg, which is 40 miles $(64.5 \mathrm{~km})$ from the sea. We do not know to what extent this species penetrates brackish or marine environments. The two specimens of cas 210350, 99-105 mm, were taken at the mouth of the Kerawal River in New Britain, and the two of CAs 206602, $43-116 \mathrm{~mm}$, were from a mangrove area in Palau.

No mention was made by Cuvier of dark spots on the body of the holotype, and none 
was seen when we examined the specimen. J.E.R. obtained a market specimen at Manado, Sulawesi, that also lacked spots on the body (Figure 2). No morphological or meristic differences could be found between spotted and unspotted specimens. Kublia rupestris is known to be more silvery when taken from marine environments, so perhaps the presence or absence of spots on $K$. marginata is related to the habitat in which the fish is found.

The name Kublia marginata has been misapplied to other species, including $K$. malo, $K$. salelea, $K$. munda, $K$. sandvicensis, and $K$. xenura, perhaps because all share a black or blackish posterior margin on the caudal fin, though of various widths. Because of these misidentifications, some literature records of this species may be suspect. Masuda et al. (1984:142, pl. 127, fig. B) recorded the species from southern Japan. We have examined specimens from Taiwan, the Philippines, Indonesia, Papua New Guinea, Solomon Islands, Vanuatu, New Caledonia, Palau, and Kosrae, Caroline Islands. Ryan (1980:62) reported three species of Kublia in a checklist of the brackish and freshwater fishes of Fiji: $K$. rupestris, $K$. bilunulata (= munda), and $K$. marginata. Of the latter he wrote, "Recorded from Rewa River. I have collected several specimens from Wafbasqa village on the Wainisavulevu Creek. Up to $220 \mathrm{~mm}$." The presence of $K$. marginata in Fiji is also confirmed by Johnson Seeto (pers. comm.).

MATERIAL EXAMINED: TAIWAN, Lanyu (Orchid Island), USNM 19125, $90 \mathrm{~mm}$. INDONESIA, вмNн 32743, $107 \mathrm{~mm}$. Sulawesi, MNHN 990, $138 \mathrm{~mm}$ (holotype of Dules maculatus); врвм 26618, $93 \mathrm{~mm}$. Java, MNнN 9002, $93 \mathrm{~mm}$ (holotype of Dules marginata). PHILIPPINES, Luzon, USNM 184755, 2: 70-76 mm. Palawan, USNM 184756, 2: 93$130 \mathrm{~mm}$. PAPUA NEW GUINEA, Sepik River, Marienberg, cas 125575, $101 \mathrm{~mm}$. New Britain, CAS 210343, 2: 89-98 mm; CAS 210350, 2: 99-105 mm. PALAU, Arumonogui River, врвм 9872, $128 \mathrm{~m}$. Babelthuap, CAS 206602, 2: 43-116 mm; cas 206617, 14: 59-73 mm; CAS 210212, 3: 52-102 mm; CAs 210345, $123 \mathrm{~mm}$. SOLOMON ISLANDS, Bougainville, roм 28721, $179 \mathrm{~mm}$. VANUATU, Espiritu Santo, USNM 122849, 3:
20.5-48.5 mm. Erromango, USNM 360092, 2: 73-75 mm. NEW CALEDONIA, MNHN 1992-610, 15: 42-148 mm; MNHN 1992-616, 4: 86-123 $\mathrm{mm}$. CAROLINE ISLANDS, Kosrae (Kusaie), USNM 163477, 80 mm; USNM 65886, 5: 76-112 mm; USNM 65887, $99 \mathrm{~mm}$.

Kublia mugil (Forster)

Figures 4, 5; Tables 1-3

Sciaena mugil Forster in Bloch and Schneider, 1801:541 (type locality, Tahiti).

Dules taeniurus Cuvier in Cuvier and Valenciennes, 1829:114 (type locality, Java).

Perca argentea Bennett, 1830, pl. 22 (type locality, Sri Lanka) (homonym of $P$. argentea Linnaeus).

Dules Bennetti Bleeker, 1853:32 (type locality, Sri Lanka) (new name for Perca argentea Bennett).

Kublia arge Jordan \& Bollman, 1890:159 (type locality, San Cristóbal, Galápagos Islands).

Dules taeniurus malpeloensis Fowler, 1944:301, fig. 176 (type locality, Malpelo Island, Colombia).

Diagnosis: Dorsal-fin rays $\mathrm{X}, 10-11$ (usually 10); anal-fin rays III,10-12 (usually 11); pectoral-fin rays $13-15$; lateral-line scales 49-52 (usually 51); gill rakers 9-11 + 24-27; preorbital serrae 11-14; body depth 2.753.05 in SL; caudal fin deeply forked, the caudal concavity $1.85-2.6$ in head length. Silvery, the front of snout and chin blackish; caudal fin white with a median dark stripe and two broad oblique black bands across each lobe, the lobe tips white; a dusky band in outer part of soft portion of dorsal fin except for white tip of high anterior part. Juveniles of about 20-30 $\mathrm{mm}$ SL have the median and outer black bands in the caudal-fin lobes, but the middle band is represented only by a black spot basally in the outer part of each lobe. Largest specimen examined, $194 \mathrm{~mm}$ SL.

REMARKs: Most authors have used the name Kublia taeniura (Cuvier) for this species. Randall (1973:187) showed that the earliest name is $K$. mugil (Forster in Bloch and Schneider, 1801).

Kublia mugil is the most wide-ranging species of the genus, occurring from the Red 


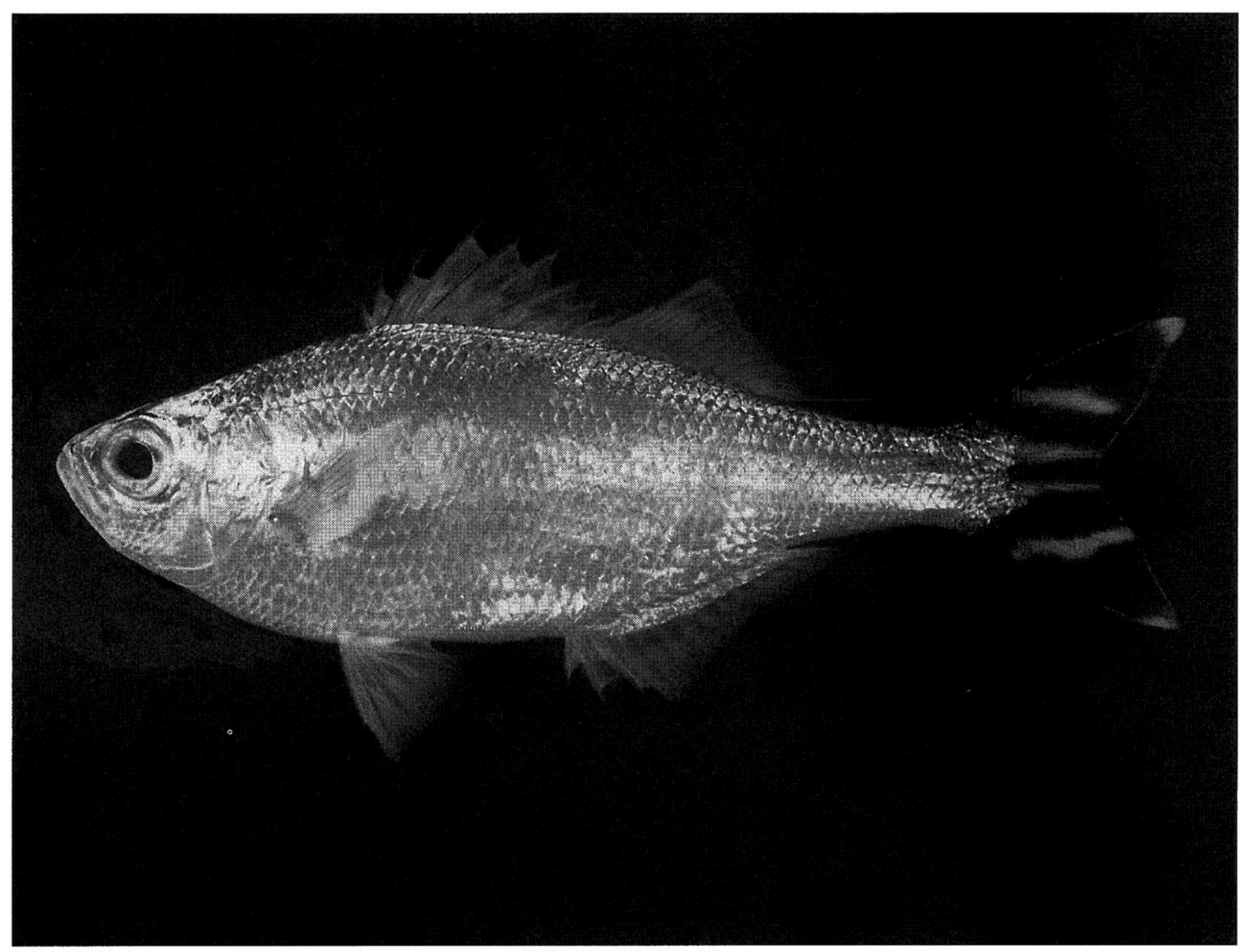

Figure 4. Kublia mugil, врвм 7057, $175 \mathrm{~mm}$ SL, Minami Tori Shima (Marcus Island).

Sea and entire coast of East Africa to the eastern Pacific, where it ranges from Baja California to Colombia, including the Revillagigedo Islands, Clipperton Island, Isla del Coco, Galápagos Islands, and Malpelo Island. In the western Pacific it is distributed from southern Japan to central New South Wales and Lord Howe Island. It is absent from Easter Island, Pitcairn Islands, Marquesas Islands, and the Hawaiian Islands; the record from Johnston Island by Smith and Swain (1883:128), followed by Jordan and Evermann (1905:209, fig. 81), is a misidentification of $K$. marginata (= sandvicensis), as shown by Gosline (1955:451).

In the western Indian Ocean and the Red Sea Kublia mugil usually has 10 anal soft rays compared with 11 for Pacific specimens, and modally 49 instead of 51 lateral-line scales. Should further study demonstrate that the western Indian Ocean form is a distinct species, or if a subspecific name is needed, $K$. stermeckii Steindachner (1898), type locality Gulf of Aqaba, Red Sea, is available.

Kublia mugil typically occurs along exposed rocky shores. The young are common in tide pools, and adults are often seen in aggregations. Van der Elst (1981:184) reported that it is occasionally found in estuaries; however, Jordan and Seale (1906:255) wrote, "This species, unlike the others of the genus, never enters fresh water,..." Van der Elst stated that adults are mainly nocturnal and feed principally on planktonic crustaceans. Juveniles are seen throughout the year along the Natal coast, indicating year-around spawning.

MATERIAL EXAMINED: COLOMBIA, Malpelo Island, ANsp 70250, $116 \mathrm{~mm}$ (holotype of Dules taeniurus malpeloensis). GALÁ- 


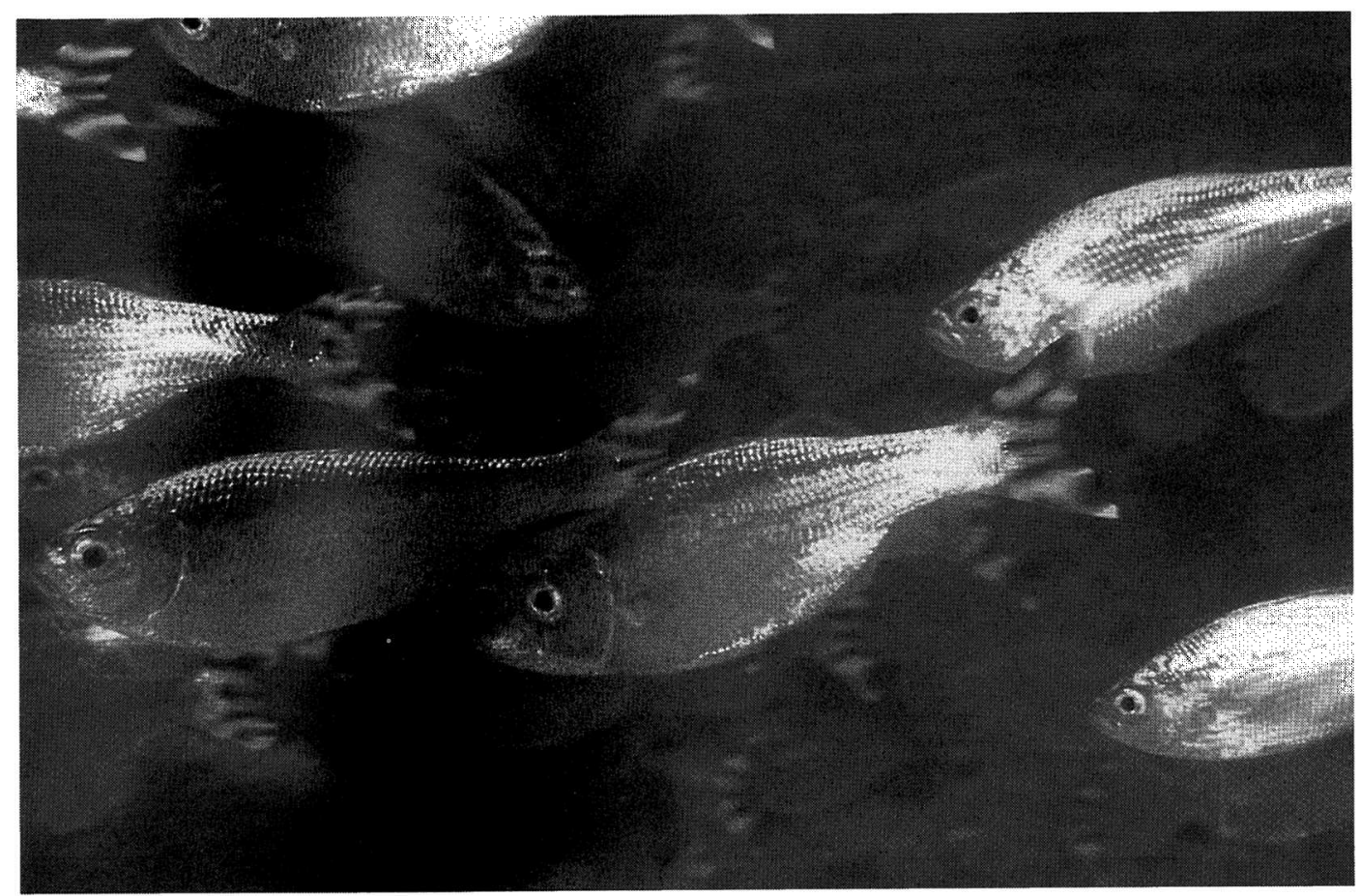

FIGURE 5. School of Kublia mugil, Enewetak Atoll, Marshall Islands.

PAGOS ISLANDS, San Cristóbal, USNM 41169, 2: $102-118 \mathrm{~mm}$ (syntypes of Kublia arge). Tower Island, cas 37453, $113.5 \mathrm{~mm}$. ISLA DEL COCO, LACM 22870, $111 \mathrm{~mm}$; LACM 35473-2, 3: 50-65 mm. REVILLAGIGEDO ISLANDS, Clarion Island, LACM 23718, 9: 54-101 mm; USNM 59839, 4: 119-158 mm. Socorro Island, LACM W53-50, 8: 167-194 mm. CLIPPERTON ISLAND, LACM W59-296, 2: 137-140 mm. SOCIETY ISLANDS, Moorea, CAS 210198, $82 \mathrm{~mm}$; CAS 210344, 4: 87-110 mm. RAPA, вРвм 17234, 3: 22-59 mm. AMERICAN SAMOA, Rose Atoll, врвм 25903, $178 \mathrm{~mm}$. WESTERN SAMOA, Upolu, врвм 5953, $93 \mathrm{~mm}$. TONGA, Tongatapu, в Рвм 37992, 3: 20-30 mm. Vava'u, вРвм $38050,27 \mathrm{~mm}$; врвм 28250, $23 \mathrm{~mm}$. VANUATU, Efaté, врвм 870, $109 \mathrm{~mm}$; врвм 1020, $159 \mathrm{~mm}$; ВРВм 10733, 8: 18-49 mm; врвм 19737, 4: 21-24 mm. CORAL SEA, Chesterfield Islands, врвм 33738, $136 \mathrm{~mm}$.
NORFOLK ISLAND, врвм 34582, 118 mm. MINAMI TORI SHIMA (MARCUS ISLAND), вРвм 2416, 2: 45-51 mm; врвм 7057, $175 \mathrm{~mm}$; врвм 8584, 6: 50-182 mm. CAROLINE ISLANDS, Puluwat Atoll, врвм 24632, 2: 71-77 mm. Lamorek Island, врвм 24621, $51 \mathrm{~mm}$. PALAU, Augulpelu Reef, cas 210348, 14: 89-110 mm. HELEN ISLAND ( $\left.3^{\circ} 52^{\prime} \mathrm{N}, 131^{\circ} 49^{\prime} \mathrm{E}\right)$, врвм 24621 , 13: 22-86 mm. TAIWAN, врвм 23199, 6: 23-41 mm; врвм 23248, $46 \mathrm{~mm}$. INDONESIA, Java, MNHN 166, $75.3 \mathrm{~mm}$ (holotype of Dules taeniurus). COCOS-KEELING ISLANDS, ANSP 131120-22, 14: 27.5-61 mm; ANSP $131169,2: 40.5-44 \mathrm{~mm}$. ANDAMAN SEA, Thailand, Similan Islands, врвм 22808, 3: 73-85 mm. MASCARENE ISLANDS, Réunion, врвм 20061, 4: 68-82 mm. MADAGASCAR, MNHN 32156, 96 mm. SOUTH AFRICA, Transkei, врвм 36795, 30: 32-98 mm. OMAN, south coast, врвм 36068, 7: 53-105 mm. RED SEA, Gulf 
TABLE 3: Gill-Raker Counts of

\begin{tabular}{|c|c|c|c|c|c|c|c|c|c|c|c|c|c|c|c|c|c|c|c|c|c|c|}
\hline \multirow[b]{2}{*}{ Species } & \multicolumn{7}{|c|}{ Upper-Limb Rakers } & \multicolumn{15}{|c|}{ Lower-Limb Rakers ${ }^{a}$} \\
\hline & 7 & 8 & 9 & 10 & 11 & 12 & 13 & 16 & 17 & 18 & 19 & 20 & 21 & 22 & 23 & 24 & 25 & 26 & 27 & 28 & 29 & 30 \\
\hline malo & & 1 & 16 & 6 & & & & & & & & 3 & 12 & 8 & & & & & & & & \\
\hline marginata & 18 & 17 & 1 & & & & & 2 & 11 & 17 & 6 & & & & & & & & & & & \\
\hline mugil & & & 11 & 14 & 5 & & & & & & & & & & & 3 & 14 & 11 & 2 & & & \\
\hline munda & & & 2 & 10 & 6 & & & & & & & & & & 1 & 3 & 9 & 5 & & & & \\
\hline nutabunda & & & & 5 & 12 & 1 & & & & & & & & & & 2 & 8 & 6 & 2 & & & \\
\hline petiti & & & 3 & 19 & 5 & & & & & & & & & & & 3 & 12 & 8 & 4 & & & \\
\hline rupestris & 2 & 8 & 12 & & & & & & 3 & 13 & 6 & & & & & & & & & & & \\
\hline salelea. & & & 4 & 5 & 3 & & & & & & & & & & & 7 & 4 & 1 & & & & \\
\hline sandvicensis & & & & & 15 & 30 & 8 & & & & & & & & & & & & 8 & 21 & 19 & 5 \\
\hline xenura & & & 3 & 26 & 19 & 1 & & & & & & & & & & & 2 & 25 & 17 & 5 & & \\
\hline
\end{tabular}

${ }^{a}$ Gill raker at angle included in lower-limb count.

of Aqaba, врвм 35707, $152 \mathrm{~mm}$; нUј 3620, 3: 145-165 mm; HUJ 91119, 2: 72-78 mm; HUJ 17089, 4: 47-52 mm.

\section{Kublia munda (De Vis)}

Figure 6; Tables 1-3

Herops munda De Vis, 1884:392 (type locality, Cardwell, Queensland).

Dules bumilis De Vis, 1884:396 (type locality, Queensland).

Kublia proxima Kendall \& Goldsborough, 1911:282, pl. 3, fig. 2 (type locality, Fiji).

Kublia bilunulata Herre, 1935:404 (type locality, small river flowing into Suva Harbor, Viti Levu, Fiji); Herre, 1936:145, fig. 7 .

DiAgnosis: Dorsal-fin rays $\mathrm{X}, 10-11$ (rarely 10); anal-fin rays III,11; pectoral-fin rays 13-14 (usually 14); lateral-line scales 4749; gill rakers $9-11+23-26$; preorbital serrae 14-21; body depth $2.55-2.85$ in SL; orbit diameter $2.55-2.8$ in head length; maxilla usually reaching to below anterior margin of pupil; caudal fin forked, the caudal concavity 2.5-3.0 in head length. Color silvery, the front of lips and upper half of snout blackish; caudal fin yellow with a very broad black posterior margin, the upper and lower margins narrowly black, but broadening toward base, often connecting across base of fin. Largest specimen examined, $134 \mathrm{~mm}$ SL.
REMARKS: All specimens for which there is information on habitat were taken from brackish or fresh water. Ryan (1980:62) identified specimens he collected in streams around Suva, Fiji, as K. bilunulata; he remarked on their having "brilliant yellow caudal fins." Johnson Seeto (pers. comm.) informed us that $K$. munda is typically found in brackish water in Fiji, in contrast to $K$. rupestris and $K$. marginata that occur in fresh water.

De Vis (1884) described Herops munda as a new genus and species of priacanthid fish from a single 5 -inch $(13-\mathrm{cm})$ specimen from Cardwell, Queensland. There was no mention of its being taken in fresh water or in the sea. In the same publication, four pages later, he described Dules bumilis from one 4-inch $(10-\mathrm{cm})$ specimen, giving only Queensland as the locality.

Kendall and Goldsborough (1911:283) differentiated their Kublia proxima from Dules bumilis De Vis by its having a larger eye, shorter snout, and longer third anal-fin spine than bumilis. They quoted De Vis, "In $D$. bumilis the second anal spine is as long as and stronger than the third."

McCulloch (1929:167) placed Dules bumilis in the synonymy of Kublia munda. He was followed by Paxton et al. (1989:540), who gave the range of $K$. munda in Australia as NE Queensland from Cape York to Cardwell $\left(18^{\circ} 16^{\prime} \mathrm{S}\right)$. 
Central Pacific Species of Kublia

Total Gill Rakers

$\begin{array}{lllllllllllllllllllll}23 & 24 & 25 & 26 & 27 & 28 & 29 & 30 & 31 & 32 & 33 & 34 & 35 & 36 & 37 & 38 & 39 & 40 & 41 & 42 & 43\end{array}$

malo

marginata

mugil

munda

nutabunda

petiti

rupestris

salelea

sandvicensis

xenura

$\begin{array}{llllll}2 & 7 & 12 & 10 & 4 & 1\end{array}$

$\begin{array}{llll}1 & 12 & 5 & 4\end{array}$

$\begin{array}{rrrrrr}3 & 13 & 8 & 4 & 2 \\ 4 & 9 & 4 & 1 & \\ 2 & 2 & 6 & 6 & 2 \\ 4 & 11 & 7 & 3 & 2\end{array}$

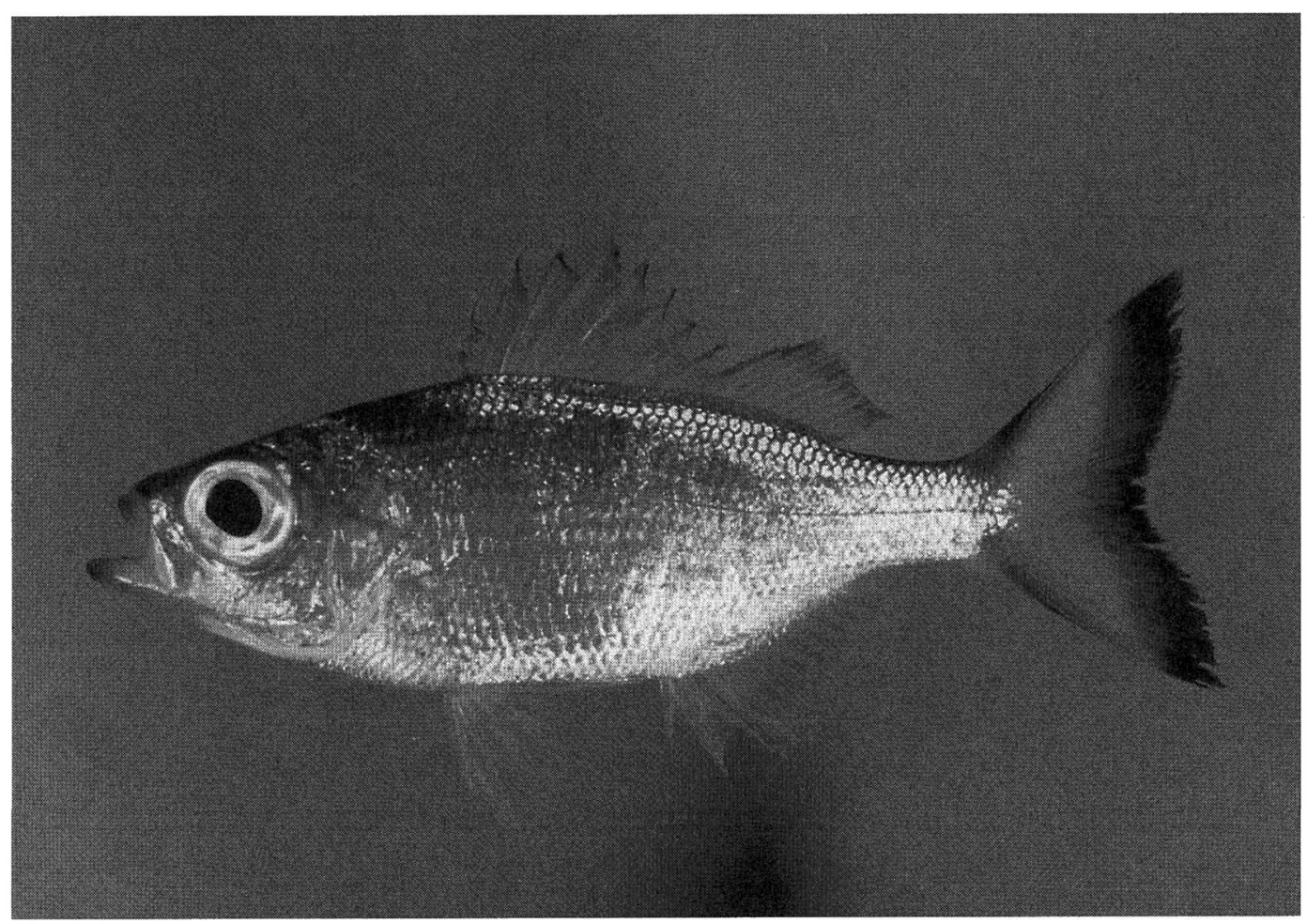

Figure 6. Kublia munda, rom 51907, 72 mm, mangroves, Viti Levu, Fiji (R. Winterbottom).

McCulloch listed Kublia proxima as a synonym of $K$. munda. He was followed by Fowler (1949:49), who also relegated K. bilunulata to the synonymy of $K$. munda.

We obtained the following counts and measurements of a syntype of Kublia munda in the Australian Museum (AMs I.421, 105 mm SL) from Sally Reader: pectoral-fin rays 13 (14 on the other side); lateral-line scales 50 ; gill rakers $12+25$; preorbital serrae 13 ; 


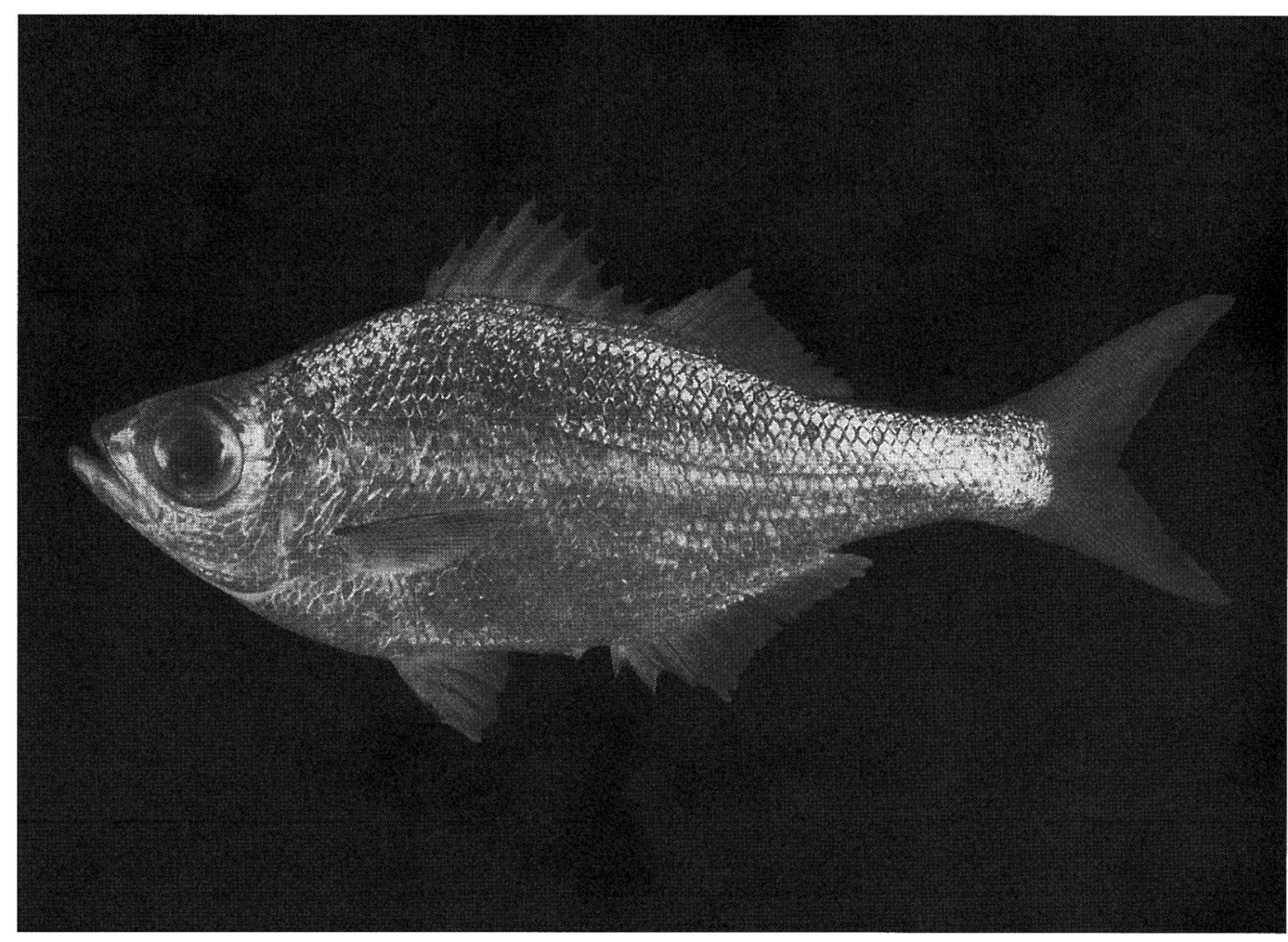

FIGURE 7. Kublia nutabunda, вРвм 6626, $230 \mathrm{~mm}$ SL, Easter Island.

body depth $42 \mathrm{~mm}$; head length $36 \mathrm{~mm}$; snout length $7.25 \mathrm{~mm}$; fleshy orbit diameter $14 \mathrm{~mm}$; second anal spine $13.9 \mathrm{~mm}$; and third anal spine $15.6 \mathrm{~mm}$. Jeff Johnson of the Queensland Museum provided the following counts of the holotype of Kublia bumilis (QM I.22, $85 \mathrm{~mm} \mathrm{SL):} \mathrm{pectoral} \mathrm{rays} 14$; lateral-line scales 49; gill rakers $11+25$.

From these data; our examination of specimens from Fiji, New Caledonia, and Vanuatu that we had initially identified as Kublia proxima; and De Vis' color note for the caudal fin of both munda and bumilis, "Caudal broadly dark-edged all around," we regard $K$. proxima as a probable synonym of $K$. munda.

MATERIAL EXAMINED: FIJI, BMNH 1855.8.16, 2: 71-74 mm. Viti Levu, CAS 124427, 12: 21-63 mm (paratypes of Kublia bilunulata); вом 51906, $79.5 \mathrm{~mm}$; вом 51907 , 3: 68-73 mm; USNM 65889, $95 \mathrm{~mm}$ (holotype of $K$. proxima); USNM 109857, 2: 26-38 mm;
USNM 112736, $126 \mathrm{~mm}$. Totoya, UsNM 236690, $57 \mathrm{~mm}$. NEW CALEDONIA, MNHN 1992-403, 4: 32-73 mm; MNHN 1992408, 8: 34-54 mm. VANUATU, Erromango, USNM 360091, 2: 83-120 mm.

Kublia nutabunda Kendall \& Radcliffe

Figures 7-9; Tables 1-3

Kublia nutabunda Kendall \& Radcliffe, 1912:105, pl. 3, fig. 1 (type locality, Easter Island).

DIAGNosis: Dorsal-fin rays $\mathrm{X}, 11$; anal-fin rays III, $10-11$ (rarely 10 ); pectoral-fin rays 14-15 (rarely 15); lateral-line scales 49-50 (usually 50); gill rakers $10-12+24-27$; preorbital serrae 11-14 (obsolete in large specimens); body depth 2.7-3.1 in SL; dorsal profile of head of adults slightly to moderately concave; eye very large, the orbit diam- 


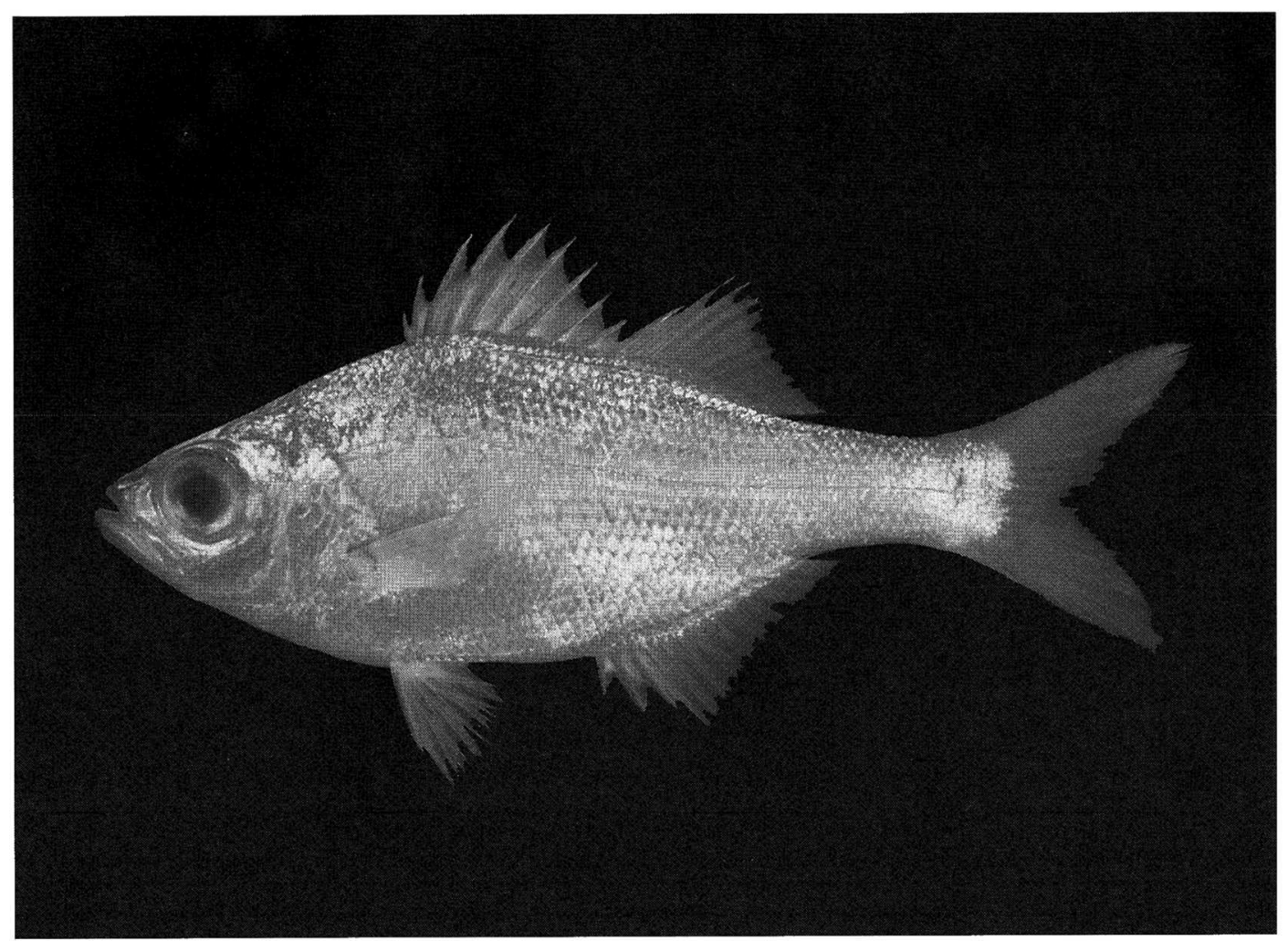

Figure 8. Kublia nutabunda, вРвм 6625, $107 \mathrm{~mm}$ SL, Easter Island.

eter $2.55-2.95$ in head length; second anal-fin spine $73-87 \%$ length of third spine; caudal fin deeply forked, the caudal concavity $1.7-$ 2.2 in head length; pelvic-fin spine $2.5-2.9$ in head length. Silvery, the fins dusky, the caudal fin with a narrow blackish posterior margin. Black margin of caudal fin more evident on juveniles than adults, and the upper and lower margins of the fin may be black as well. Largest specimen, $242 \mathrm{~mm}$ SL.

REMARKS: Kublia nutabunda is known only from Easter Island. Specimens were collected by J.E.R. and Gerald R. Allen in 1969 from along exposed rocky shore, in large tide pools, and over sand substratum near rocky shore in Anakena Bay. It was often seen in aggregations (Figure 9).

The species was described from the 115mm holotype and 90 paratypes. The holotype and 53 of the paratypes were examined by us at the U.S. National Museum of Natural History. The remaining 37 paratypes were given to the Museum of Comparative Zoology of Harvard University.

This species is most similar to Kublia sandvicensis, sharing with it the large eyes, concave dorsal head profile, and caudal-fin color. It differs slightly in pectoral-fin ray, lateral-line scale, and gill-raker counts (see Tables 1-3), in having a shorter second analfin spine relative to the length of the third anal-fin spine, and in having shorter pelvicfin spines.

MATERIAL EXAMINED: EASTER ISLAND, USNM 65550, 53: 24-95 mm (paratypes of Kublia nutabunda); USNM 65551, 115 $\mathrm{mm}$ (holotype of $K$. nutabunda); вMNH 1913.12:7.2, $162 \mathrm{~mm}$; в Рвм 6624, 13: 32-92 $\mathrm{mm}$; ВBPM 6625, 11: 32-113 $\mathrm{mm}$; вРвм 6626, 21: $227.5-242 \mathrm{~mm}$. 


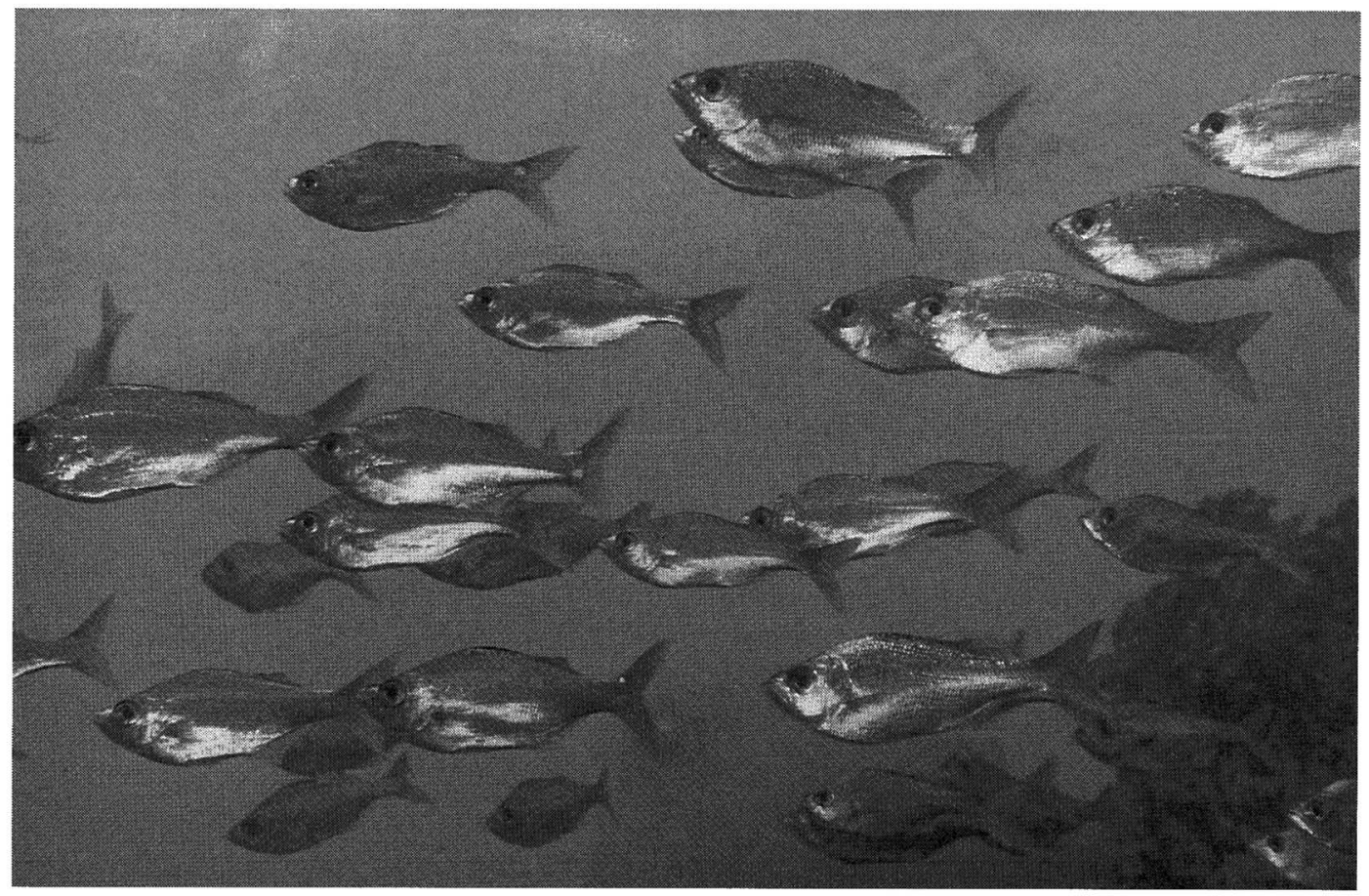

Figure 9. School of Kublia nutabunda, Easter Island.

\section{Kublia petiti Schultz}

Figures 10, 11; Tables 1-3

Dules taeniurus (non Cuvier) Fowler, 1938:70 (Nuku Hiva, Marquesas Islands).

Kublia petiti Schultz, 1943:102, fig. 7 (type locality, Hull Island, Phoenix Islands).

Dules taeniurus marquesensis Fowler, 1944:326, fig. 177 (type locality, Nuku Hiva, Marquesas Islands).

DIAGNosis: Dorsal-fin rays $\mathrm{X}, 11-12$ (usually 12); anal rays III,11-12 (usually 12); pectoral-fin rays $13-15$ (rarely 13 or 15 ); lateral-line scales 51-53 (usually 51); gill rakers $9-11+24-27$; preorbital serrae 11-20; body depth 2.6-3.1 in SL; maxilla ending beneath anterior third of eye; caudal fin forked, the caudal concavity $2.0-2.4$ in head length. Silvery, the front of the snout and chin a little blackish; naked part of caudal fin black with a large, C-shaped, white marking basally in each lobe, the lobe tips white; outer part of anterior half of soft portion of dorsal fin broadly blackish (nearly half of first few rays and adjacent membranes blackish). Largest specimen examined, $201 \mathrm{~mm}$ SL.

REMARKs: Kublia petiti is known only from the Phoenix Islands, the Marquesas Islands (where it seems to be the only species of the genus), and Malden Island in the Line Islands. It might be expected at other southern Line Islands such as Starbuck, Vostok, Flint, and Caroline Atoll (recently renamed Millennium Island), and the northern Cook Islands. J.E.R. and John L. Earle encountered a school of about 100 adults along a rocky shore at Eiao in the northern Marquesas. One specimen was collected, and an underwater photograph was taken of part of the school (Figure 11).

The 17 specimens of вРвм 25524, 25-66 $\mathrm{mm}$, were collected at Canton Atoll in the Phoenix Islands by nightlighting.

MATERIAL EXAMINED: PHOENIX ISLANDS, Hull Island, USNM 114986, 108 mm (holotype of Kublia petiti); USNM 114992, 20: $19-48 \mathrm{~mm}$ (paratypes of K. petiti). Enderbury Island, USNM 114988, 8: 49-60 mm (paratypes of $K$. petiti; three specimens of this lot 


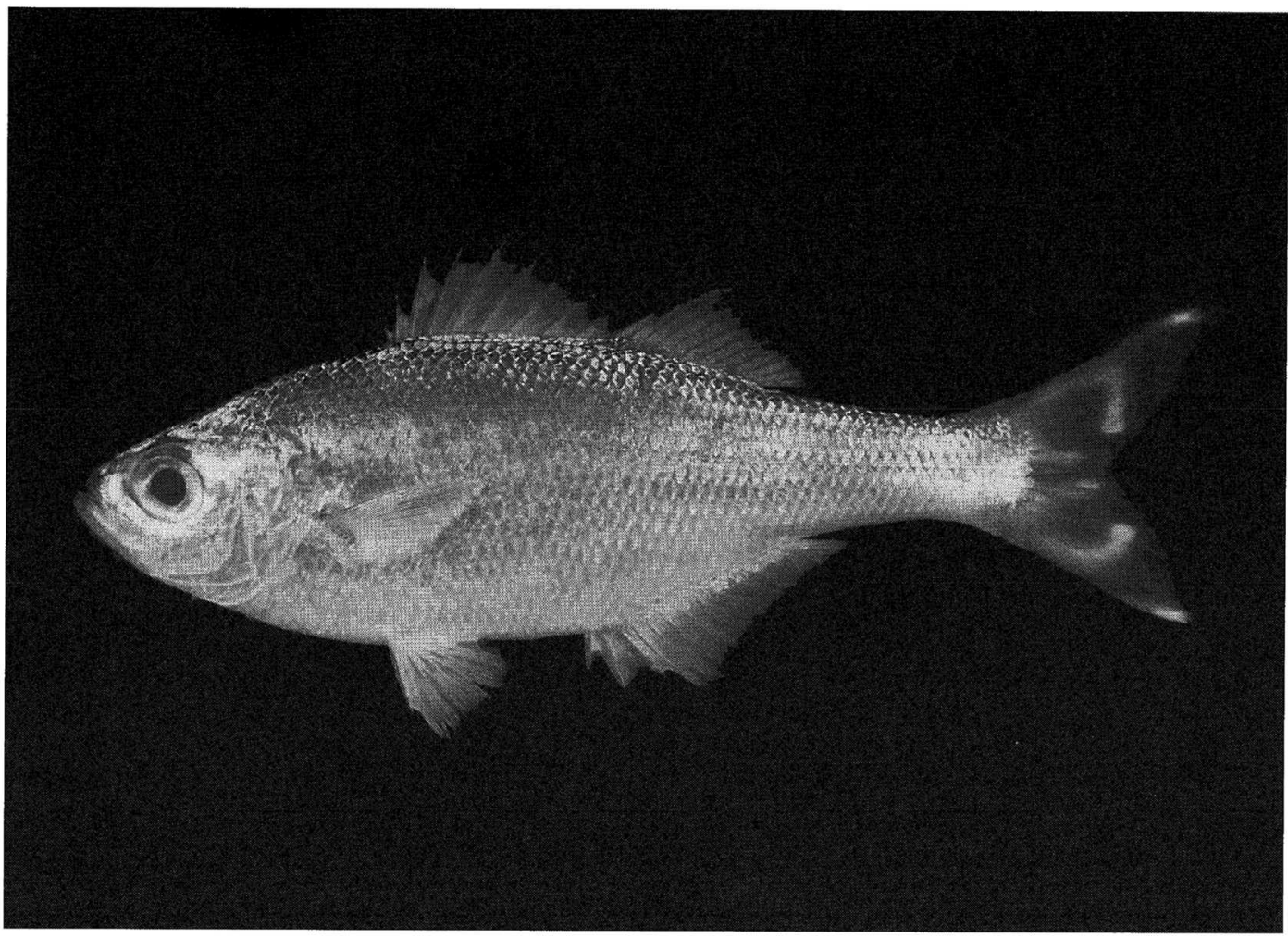

Fygure 10. Kublia petiti, вPвм 12146, $136 \mathrm{~mm}$ SL, Ua Pou, Marquesas Islands.

given to Museum of Comparative Zoology of Harvard University); USNM 114991, 69: 20$116 \mathrm{~mm}$. Canton Island, UsNm 114987, 2: 68$84 \mathrm{~mm}$ (labeled as paratypes of $K$. petiti, but not listed by Schultz [1943]); USNM 114989, 3: 64-69 mm; USNM 114990, 18: 34-105 mm (paratypes of $K$. petiti); врвм 25492, $201 \mathrm{~mm}$; врвм 25524, 17: 25-66 mm. LINE ISLANDS, Malden Island, врвм 10488, 190 mm. MARQUESAS ISLANDS, Nuku Hiva, ANsP 70063, $51.5 \mathrm{~mm}$ (holotype of Dules taeniurus marquesensis); врвм 10447, 2: 160-166 mm; вРвм 10458, 14: 68-157 mm; врвм 12649, 2: 108-149 mm. Ua Pou, врвм 12146, 6: 70-136 mm; врвм 26349, 4: 65$101 \mathrm{~mm}$. Еіао, врвм 38517, $168 \mathrm{~mm}$.

Kublia rupestris (Lacépède)

Figures 12, 13; Tables 1-3

Centropomus rupestris Lacépède, 1802:252, 273 (type locality, Réunion).
Perca ciliata Cuvier (ex Kuhl \& van Hasselt) in Cuvier and Valenciennes, 1828:52 (type locality, Java).

Dules guamensis Valenciennes in Cuvier and Valenciennes, 1831:474 (type locality, Guam).

Dules vanicolensis Valenciennes in Cuvier and Valenciennes, 1831:478 (type locality, $\mathrm{Va}$ nicolo, Santa Cruz Islands).

Dules baswellii Macleay, 1881:359 (type locality, Rockingham Bay, Queensland).

Kublia rupestris bedleyi Ogilby, 1897:767 (type locality, New Caledonia).

Kublia caerulescens Regan, 1913:376, fig. 68 (type locality, Stirling Island, Solomon Islands).

Diagnosis: Dorsal-fin rays $X, 10-11$ (usually 11 ); anal-fin rays $\mathrm{III}, 10-11$ (usually 10); pectoral-fin rays $13-14$ (usually 14); lateral-line scales 39-41; gill rakers $7-9+$ 17-19; preorbital serrae 10-15 (obsolete on 


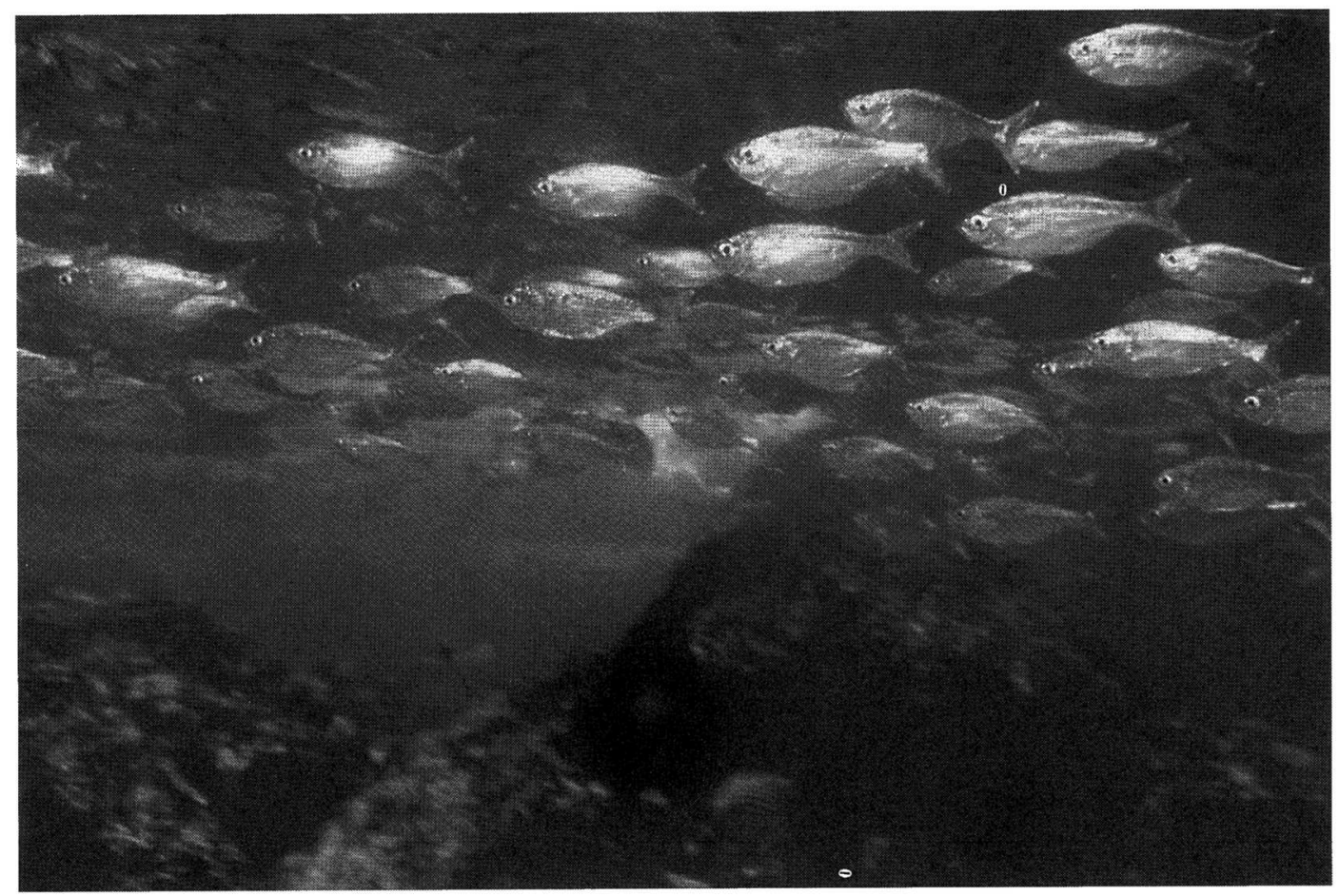

Figure 11. School of Kublia petiti, Eiao, Marquesas Islands (J. L. Earle).

large specimens); body depth $2.6-3.0$ in SL; mouth large for the genus, the maxilla reaching to below posterior half of eye; caudal fin emarginate, the lobes somewhat rounded, the caudal concavity $5.3-8.7$ in head length. Silvery, the scales dorsally on body with black edges, those on side with a black bar or spot; juveniles with a broad black zone, edged above and below in white, in soft portion of dorsal fin, and each lobe of caudal fin with a large, white-edged black spot; black areas in these fins enlarge with growth until in adults most of these fins black (the caudal with upper and lower edges and corners whitish). Reported to $450 \mathrm{~mm}$ total length and a weight of $2.7 \mathrm{~kg}$ (Smith in Smith and Heemstra [1986:508]).

REMARKS: Kublia rupestris occurs in fresh and brackish water, but it is reported to venture into adjacent marine habitats. It is, however, primarily a freshwater fish. The two specimens of CAS 210346 were taken from the Malatgaw River in Palawan at an altitude of
800 feet $(240 \mathrm{~m})$. The species ranges from East Africa to American Samoa; in the western Pacific from the Ryukyu Islands south to Queensland and New Caledonia. The records from Hawai'i by Fowler (1938, 1940, 1949) are mistakes.

We place Kublia caerulescens Regan in the synonymy of $K$. rupestris. Regan gave the number of gill rakers on the lower limb of the first gill arch as 7 . This is a probable printer's error for 17 (our count of the gill rakers of the holotype is $8+17$ ).

MATERIAL EXAMINED: MAURITIUS, вPвм 20130, $180 \mathrm{~mm}$. PHILIPPINES, Palawan, CAS 210346, 2: 137-147 mm. TAIWAN, USNM 191264, 6: 27-65 mm. PALAU, вРвм 9873, $154 \mathrm{~mm}$. SOLOMON ISLANDS, Stirling Island, вмNн 1884.3.24.95, $242 \mathrm{~mm}$ (holotype of Kublia caerulescens). Guadalcanal, cas 210191, 2: 41-48 mm; UsNM uncat., 2: 39-48 mm. VANUATU, Erromango, USNM 360093, $62 \mathrm{~mm}$. Malekula Island, CAS 125023, 3: 64-143 mm. MAR- 


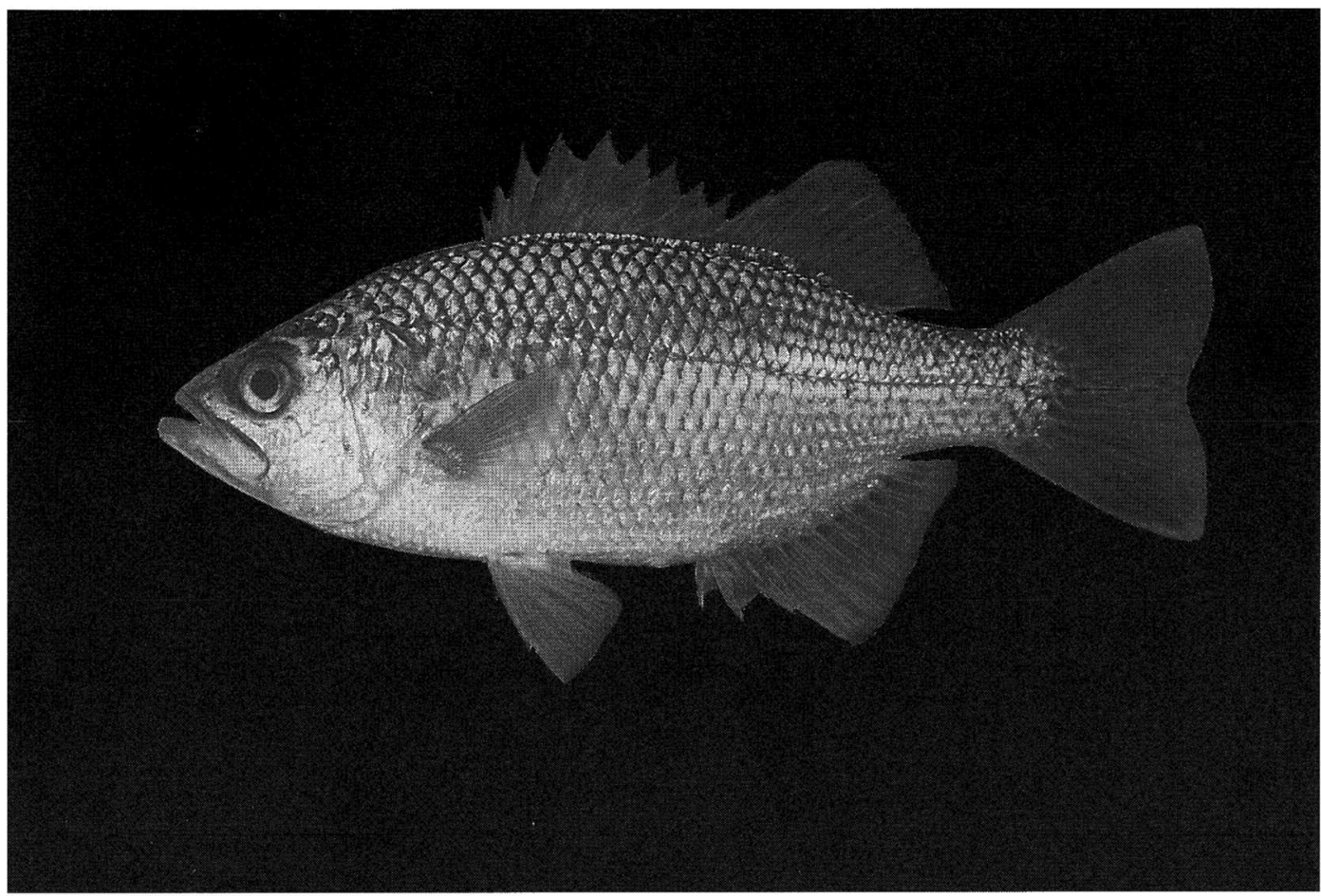

FIGURE 12. Kublia rupestris, вPBм 20130, $180 \mathrm{~mm}$ SL, Mauritius.

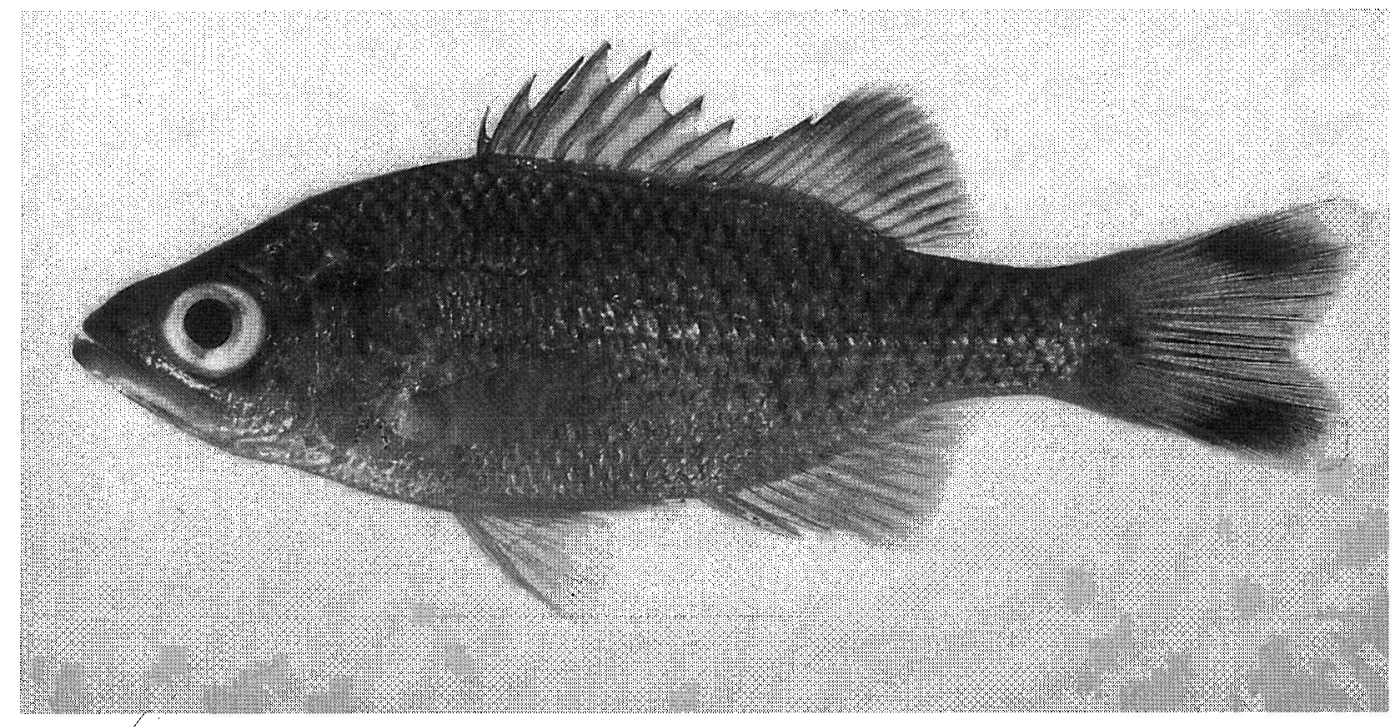

Figure 13. Kublia rupestris, usnm 360093, $62 \mathrm{~mm}$ SL, Erromango, Vanuatu (J. T. Williams). 


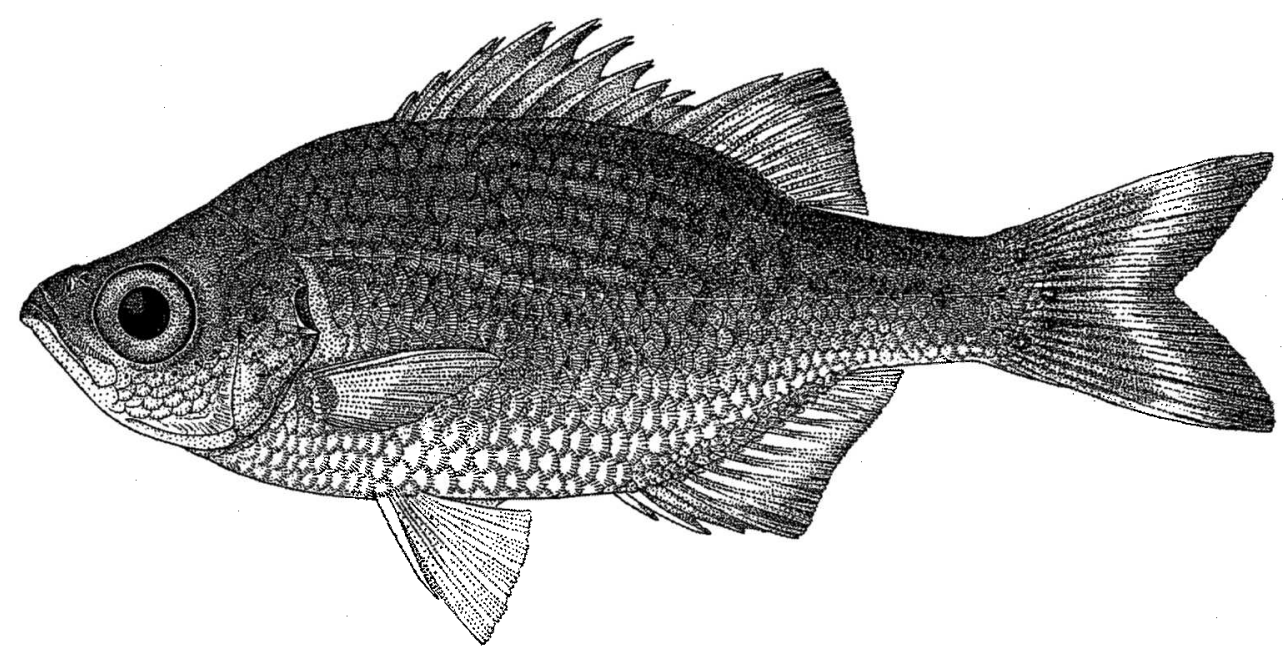

Figure 14. Holotype of Kublia salelea, USNM 114984, $95 \mathrm{~mm}$ SL, Tutuila, American Samoa (after Schultz [1943]).

IANA ISLANDS, Guam, MNHN 3060, 134 mm (syntype of Dules guamensis); врвм 91, $145 \mathrm{~mm}$; вРвм 92, $184 \mathrm{~mm}$. Saipan, USNM $150026,160 \mathrm{~mm}$. CAROLINE ISLANDS, Pohnpei (Ponape), UsNM 224342, 29: 33-149 mm. Kosrae (Kusaie), врвм 28331, 12: 48$154 \mathrm{~mm}$. FIJI, Viti Levu, CAs 5913, $54 \mathrm{~mm}$. WESTERN SAMOA, Upolu, USNM 174740, 3: 28-228 mm.

Kublia salelea Schultz

Figure 14; Tables 1-3

Kublia salelea Schultz, 1943:100, fig. 6 (type locality, Tutuila, American Samoa).

Diagnosis: Dorsal-fin rays $\mathrm{X}, 11$; anal-fin rays III, $11-12$; pectoral-fin rays 14 ; lateralline scales 40-42; gill rakers 9-11 + 24-26; preorbital serrae 23-26; body depth 2.6-3.0 in SL; orbit diameter 2.9-3.2 in head length; maxilla extending to or slightly posterior to a vertical at anterior edge of pupil; caudal fin moderately forked, the caudal concavity 2.83.1 in head length. Color in alcohol brown, the edges of the scales dorsally on body dark brown, with small dark brown spots on about upper half of body; tip of lower jaw dark brown; caudal fin with a broad, dark brown posterior margin and narrow, pale upper and lower edges; soft portions of dorsal and anal fins with a dusky outer band, broad anteriorly and narrowing posteriorly, the ray tips pale. In life probably silvery, the dark markings black or blackish. Largest specimen examined, $114 \mathrm{~mm}$.

REMARKS: Kublia salelea is currently known only from fresh water in Tutuila, American Samoa, and Upolu, Western Samoa. It was named from the native Samoan word for the species, salele.

This species is most similar to two other freshwater species, $K$. marginata from the western Pacific and $K$. malo from the Society Islands. It differs from both in its higher number of lower-limb gill rakers (Table 3).

MATERIAL EXAMINED: AMERICAN SAMOA, Tutuila, USNM 114984, $95 \mathrm{~mm}$ (holotype of Kublia salelea); USNM 114985, 32: 26-117 mm (paratypes of K. salelea; Schultz listed 37 specimens, but five were transferred to the Museum of Comparative Zoology of Harvard University). WESTERN SAMOA, Upolu, Apia, cas 72, 114 mm; CAS 109027, 10: 17-88 mm; UsNM 52276, 9: 23-94 mm (paratypes of $K$ salelea); UsNM $126279,3: 28-78$ mm; врвм 5152, $108 \mathrm{~mm}$; врвм 5370, $64 \mathrm{~mm}$. 


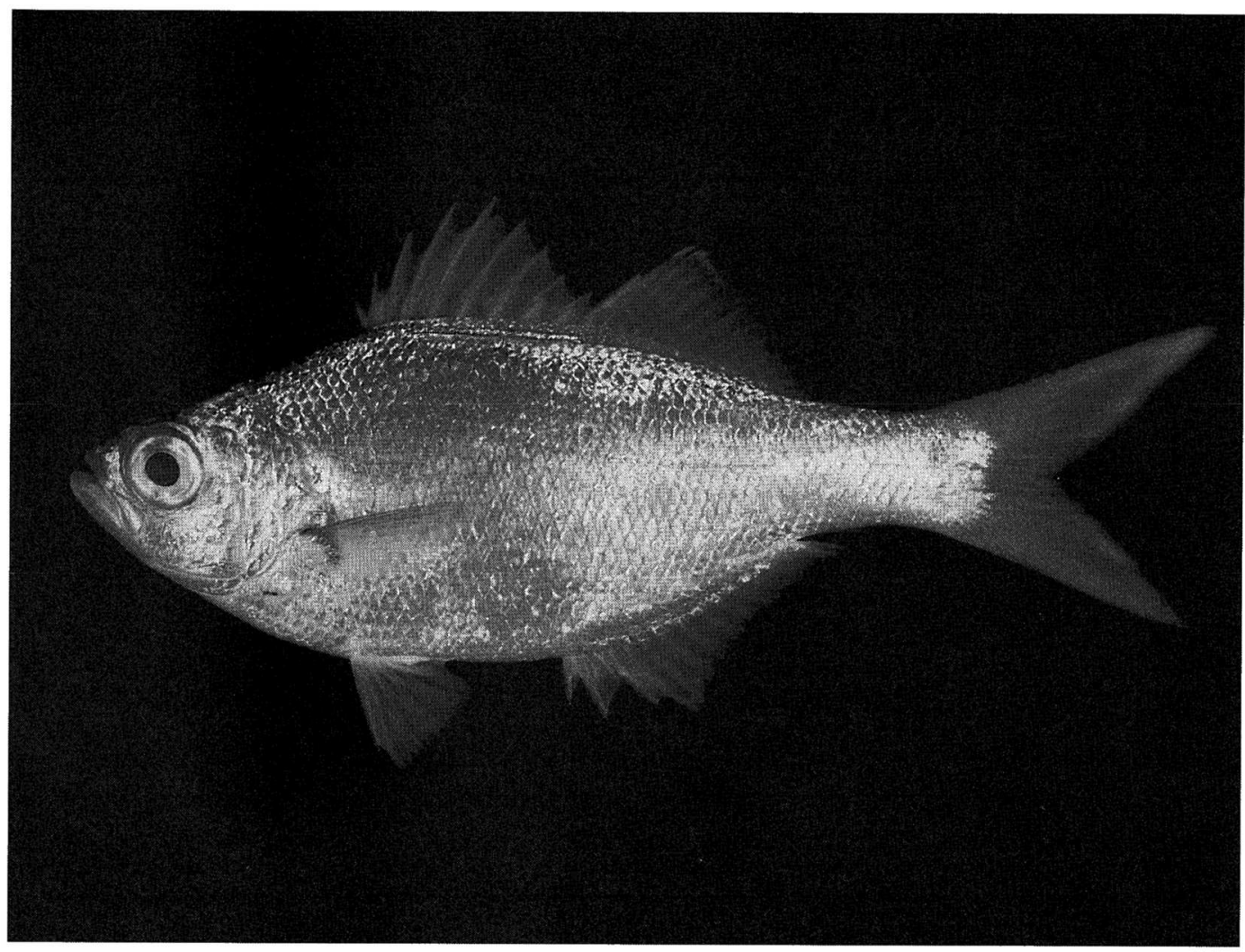

Figure 15. Kublia sandvicensis, врвм 8956, $132 \mathrm{~mm}$ SL, Johnston Island.

Kublia sandvicensis (Steindachner)

Figures 15, 16; Tables 1-3

Moronopsis argenteus, var. sandvicensis Steindachner, 1876:205 (type locality, Hawaiian Islands).

Moronopsis sandvicensis Steindachner, 1887: 230, pl. 1, fig. 1 (Hawaiian Islands).

Kublia malo (non Valenciennes) Bryan \& Herre, 1903:129 (Marcus Island $=$ Minami Tori Shima).

Kublia malo (non Valenciennes) Jordan \& Evermann (in part), 1905:207 (Hawaiian Islands).

Kublia sandvicensis Regan (in part), 1913:381 (Hawaiian Islands).

Dules sandvicensis Fowler, 1938:169 (Bora Bora).

Kublia sandvicensis Schultz, 1943:101 (Phoenix Islands).
Kublia sandvicensis Harry, 1953:82 (Raroia, Tuamotu Archipelago).

Kublia marginata (non Cuvier) Schultz in Schultz and Collaborators, 1953:327 (Marshall Islands).

Kublia marginata (non Cuvier) Gosline, 1955:471 (Johnston Island).

Kublia marginata (non Cuvier) Randall, 1955:79 (Nukunau, Gilbert Islands = Kiribati).

Kublia marginata (non Cuvier) Bagnis et al., 1972:270, figs. on pp. 270, 271 (Society Islands).

Kublia marginata (non Cuvier) Randall, 1999:12 (Pitcairn Islands).

DIAGNosis: Dorsal-fin rays X,11-12 (one of 57 specimens with 12); anal-fin rays III,1112 (one of 57 with 12); pectoral-fin rays $13-$ 15 (rarely 15); lateral-line scales 49-51 (usu- 
ally 50, rarely 49); gill rakers $11-13+27-30$; preorbital serrae 10-20; body depth 2.6-2.9 in SL; dorsal profile of head nearly straight; eye not very large, the orbit diameter 3.03.45 in head length; caudal fin strongly forked, the caudal concavity $1.45-1.7$ in head length; third anal-fin spine slightly longer than second spine (second spine 88-95\% length of third spine); pelvic-fin spine 2.3-2.9 in head length. Color silvery with a coarse silver and black reticulum dorsally on head in life; posterior edge of caudal fin blackish. Largest specimen examined, $214 \mathrm{~mm}$ SL, from Wake Island.

REMARKs: Günther (1873:24) was the first to record a species of Kublia from the Hawaiian Islands, identifying it as Dules marginatus Cuvier, and noting the Hawaiian name as "Haholehole." He also listed the species from Indonesia, Fiji, Marshall Islands, Gilbert Islands, and Society Islands.

Steindachner (1876) briefly described sandvicensis as a variety of Moronopsis argentea (Bennett, 1830), now known as a synonym of Kublia mugil. Steindachner (1887) elevated sandvicensis to a species, described it more fully, and provided a very good drawing. $\mathrm{He}$ gave the total length of his type specimens as $26-28 \mathrm{~cm}$ but did not indicate how many he examined, nor was any designated as a holotype.

Boulenger (1895:40) correctly placed the Hawaiian species in Kublia, but used the specific name malo and put Steindachner's sandvicensis in synonymy. He was followed in the use of the name Kublia malo by Fowler (1900), Steindachner (1901), Jenkins (1903), Snyder (1904), Jordan and Evermann (1905), and Jordan and Jordan (1922).

In a revision of Kublia, Regan (1913:381) resurrected the name $K$. sandvicensis and listed specimens from the Hawaiian Islands and Tahiti.

Gosline (1955:471) showed that Kublia sandvicensis is endemic to the Hawaiian Islands; he recorded specimens from throughout the archipelago.

When only one endemic species of Kublia was known from the Hawaiian Islands, there was no question that the correct name was $K$. sandvicensis. With the recent discovery that there are two species in the Hawaiian Islands,
Steindachner's description and illustration were carefully analyzed. Unfortunately he did not give the number of pectoral-fin rays or a count of the gill rakers, but he did give the count of lateral-line scales as 51 plus 5 extending onto the base of the caudal fin. As shown in Table 2, this count strongly favors the species that ranges to many other islands besides those of Hawaiti. The drawing shows a nearly straight dorsal profile of the head (actually the part from the interorbital to the dorsal fin origin is slightly convex). A specimen of the endemic Hawaiian species of this size would have a slightly concave profile. The eye size of 3 in the head length also slightly favors the wide-ranging species. There is therefore little doubt from these characters that the name Kublia sandvicensis can no longer be used for the endemic Hawaiian species.

Ernst Mikschi, curator of fishes of the Naturhistorische Museum in Vienna, was asked to check the syntypes of Moronopsis sandvicensis for confirmation of the lateral-line scale count and to make counts of pectoral-fin rays and gill rakers. He reported that only one specimen, NMW 42484, is on the shelf as a syntype, but it is too large to have been one of Steindachner's types. He searched for the missing syntypes but was unable to find them. $\mathrm{He}$ added that this does not mean they are lost because an estimated $40 \%$ of the NMW fish collection is uncataloged.

This species has been misidentified most recently as $K$. marginata. As noted above, $K$. marginata is a freshwater species from the western Pacific. Fowler (1928:169) recorded many specimens of Kublia marginata from the Hawaiian Islands, as well as other localities, but the meristic data he provided, such as lateral-line scales $38-47$, indicate that his specimens could not be from Hawai' $i$.

Initially there seemed to be no available name for the endemic Hawaiian species of Kublia that has long been misidentified as sandvicensis; however, as is explained in the next species treatment, Kublia xenura (Jordan \& Gilbert) is based on two specimens of this species, overlooked because of an erroneous type locality of El Salvador, Central America. Judging from the meristic data, general morphology, and caudal-fin coloration, $K$. 


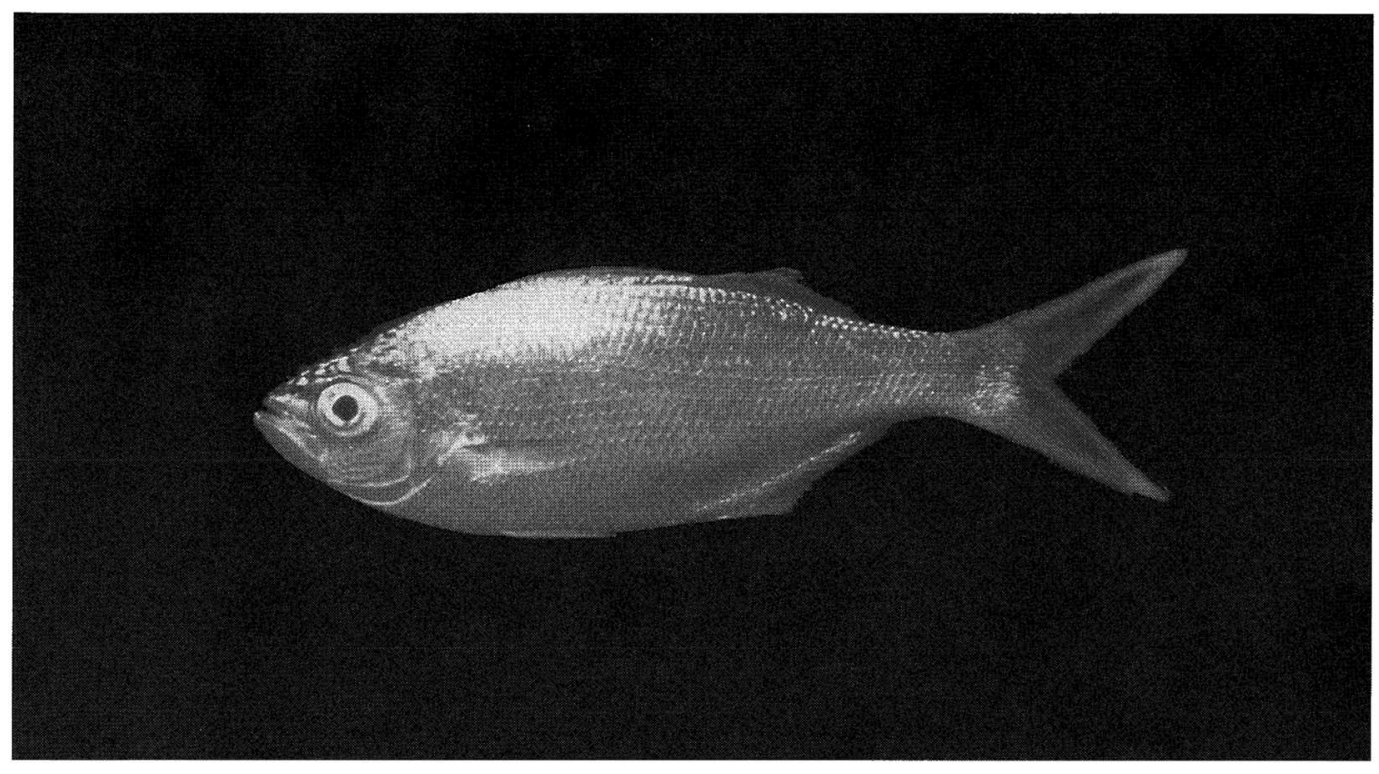

FIgURE 16. Kublia sandvicensis, Maui, Hawaiian Islands.

sandvicensis is most similar to the endemic Easter Island $K$. nutabunda and the endemic Hawaiian $K$. xenura. It differs from both in its smaller eye, straighter dorsal head profile, higher gill-raker counts, and the reticular color pattern dorsally on the head. In addition, it differs from xenura in the strongly modal count of 14 pectoral-fin rays versus 15 for xenura.

Gosline (1955) compared Hawaiian specimens that he identified as $K$. sandvicensis (now $K$. xenura), and specimens of $K$. marginata (now $K$. sandvicensis), noting that the latter has a lower average pectoral-ray count and a higher gill-raker count. He examined specimens of what he called $K$. marginata from Johnston Island, Line Islands, Phoenix Islands, northern Cook Islands, Wake Island, and Minami Tori Shima (Marcus Island), and he accepted the record by Schultz in Schultz and Collaborators (1953:324) from the Marshall Islands. He had no specimens of marginata from the Hawaiian Islands; however, we now know from a comment made by Tester and Takata (1953:7), in their report on a study of the biology of this species, that their material included both species. They wrote, "In some of the small aholehole, the top of the head is whitish with black reticulations...." It is also clear from the description of Kublia malo by Jordan and Evermann (1905:207) that they had specimens of both Hawaiian species of the genus.

We can add the Pitcairn Islands, Tuamotu Archipelago, Society Islands, Rapa, and Kiribati to the localities for this species given by Gosline. Meristic data for this species for Tables 1-3 were taken from all available specimens except juveniles; no differences were noted in counts between Hawaiian specimens and those from other localities.

Two adult specimens from Wake Island, врвм 3929, 172-212 $\mathrm{mm}$, are perplexing in having 14 pectoral-fin rays, $50-51$ lateral-line scales, and $12+28$ gill rakers, hence the counts for sandvicensis, but the largest specimen has an unusually large eye for the species, 2.8 in the head length, and the smallest an eye size that is marginal for the species, 3.0 in the head. Four other specimens from Wake, cas 150071, 3: 41-97 mm, and cas $212859,214 \mathrm{~mm} \mathrm{SL}$, are typical in all respects to sandvicensis, including an eye diameter 3.3 in the head length for the large specimen. More specimens should be obtained from Wake Island. 


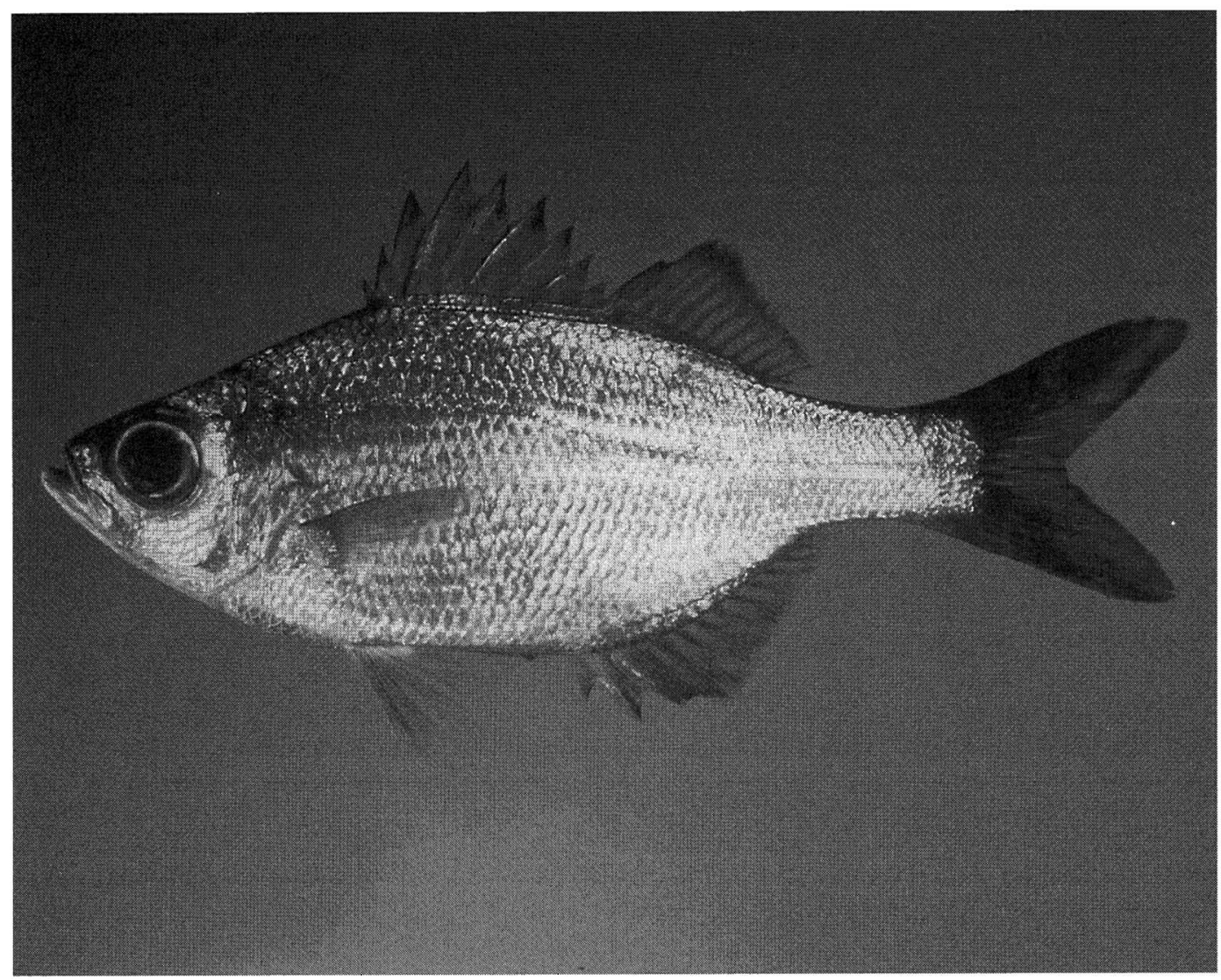

Figure 17. Kublia xenuta, BPBM 11533, $121 \mathrm{~mm}$, O'ahu, Hawaiian Islands.

MATERIAL EXAMINED: HAWAIIAN ISLANDS, Hawai'i, Puakō Bay, usnm 55128, $134 \mathrm{~mm}$. Kalapana, AMS I.40256-001, $171 \mathrm{~mm}$; ANSP $177868,186.5 \mathrm{~mm}$; BMNH 2000.5.8.1, $183 \mathrm{~mm}$; вРвм 38712, $187 \mathrm{~mm}$; CAS 212862, $157 \mathrm{~mm}$; LACM 54291-1, 182.5 mm; MNHN 2000-1060, $187.5 \mathrm{~mm}$; ROM 72244, $190 \mathrm{~mm}$; USNM 361238, $183.5 \mathrm{~mm}$. O'ahu, врвм 37390, 4: 28-97.5 $\mathrm{mm}$; CAS 213279, 14: 44-133 mm. JOHNSTON ISLAND, врвм 3928, $110 \mathrm{~mm}$; врвм 3930 , $33 \mathrm{~mm}$; вРвм 8956, $132 \mathrm{~mm}$. PITCAIRN ISLANDS, Ducie Atoll, врвм 12250, 2: 159-161 mm; в Рвм 17125, 2: 200-202 mm. Henderson Island, врвм 17063, 3: $25-$ 159 mm. Pitcairn Island, врвм 16737, 8: 109-165 mm. TUAMOTU ARCHIPELAGO, Rangiroa Atoll, вPBM 10253, 7: 49$81 \mathrm{~mm}$. RAPA, врвм 12881, 23: 43-98.5 mm. Marotiri (Ilots de Bass), врвм 10354, 3: 97.5-115 mm. SOCIETY ISLANDS, Tahiti, вмNн 73.4.3.65, $167 \mathrm{~mm}$. COOK ISLANDS, Mangaia, CAS 210189, 4: 24.5 $52 \mathrm{~mm}$. LINE ISLANDS, Malden Island, врвм 38724, $212 \mathrm{~mm}$. Tabuaeran (Fanning Island), врвм 10904, $198 \mathrm{~mm}$. PHOENIX ISLANDS, Hull Island, USNM 11500, 3: $24-$ $114 \mathrm{~mm}$. WAKE ISLAND, CAS 150071, 3: 41-97 mm; CAS 212859, $214 \mathrm{~mm}$. MINAMI TORI SHIMA (MARCUS ISLAND), BPBM 7058-7060, 12: 49-198 mm.

Kublia xenura (Jordan \& Gilbert)

Figures 17-19; Tables 1-3

Dules marginatus (non Cuvier) Günther (in part), 1873:24 (Hawaiian Islands).

Xenicbtbys xenurus Jordan \& Gilbert, 
1882:454 (questioned type locality, San Salvador, El Salvador).

Kublia malo (non Valenciennes) Boulenger (in part), 1895:41 (Hawaiian Islands).

Kublia malo (non Valenciennes) Steindachner, 1901:483 (Laysan and Honolulu).

Kublia malo (non Valenciennes) Jordan \& Evermann (in part), 1905:207 (Hawaiian Islands).

Kublia sandvicensis (non Steindachner) Regan (in part), 1913:381 (Hawaiian Islands).

Kublia sandvicensis (non Steindachner) Gosline, 1955:471 (Hawaiian Islands).

Kublia sandvicensis (non Steindachner) Gosline \& Brock, 1960:159 (Hawaiian Islands).

Kublia sandvicensis (non Steindachner) Randall, 1985:16, fig. 32 (Hawaiian Islands).

DiAgnosis: Dorsal-fin rays $\mathrm{X}, 11-12$ (rarely 12); anal-fin rays $\mathrm{III}, 10-11$ (rarely 10); pectoral-fin rays $14-15$ (usually 15); lateralline scales 49-51 (usually 49, rarely 51 ); gill rakers $9-12+25-28$; preorbital serrae 1118; body depth $2.3-2.7$ in SL; dorsal profile of head of adults slightly concave; eye large, 2.6-2.95 in head length; second anal spine $86-98 \%$ length of third spine; pelvic spine $2.2-2.5$ in head length; caudal fin deeply forked, the caudal concavity $1.8-2.0$ in head length. Silvery, the caudal fin dusky to dark. gray with a narrow black posterior margin and often a pale submarginal band. Largest specimen examined, $222 \mathrm{~mm} \mathrm{SL}$, from Laysan.

REMARKS: The recent discovery of a second species of Kublia from the Hawaiian Islands prompted us to look at Steindachner's description of sandvicensis more closely. Regrettably, it strongly favors the species that is the least common in Hawai'i and ranges well beyond the Hawaiian Islands. The only other available name for the endemic Hawaiian species of Kublia is K. xenura (Jordan \& Gilbert, 1882).

Jordan and Evermann (1896:1015) reclassified the haemulid fish Xenichtbys xenurus Jordan \& Gilbert, "supposed to come from San Salvador," as Kublia xenura. They wrote, "known from two specimens in the U.S. National Museum, bearing the label 'San Salvador. J. M. Dow.' But it is possible that they were brought by Dr. Stimpson from China and Kublia xenura may not be an American fish at all." Jeffrey T. Williams examined the two syntypes of Kublia xenura, USNM 4356, 122-132 mm SL, for us. He counted 15-15 pectoral-fin rays for one specimen and 15-14 for the other, 49 lateral-line scales for each, and $11+26$ and $11+27$ gill rakers. The endemic Hawaiian species of Kublia is the only species with modally 15 pectoral rays, modally 49 lateral-line scales, and the only one with primary counts of 26 and 27 lower-limb gill rakers (see Tables 1-3). The largest syntype was sent to us on loan; we here designate it the lectotype. We conclude that the two syntypes of $K$. xenura are the Hawaiian endemic species long misidentified as $K$. sandvicensis.

Kublia xenura is a common inshore fish in Hawai' $i$ that is often seen in schools (Figure 19). Tester and Takata (1953) prepared an extensive report on its biology (as $K$. sandvicensis) because it seemed to have potential as a tuna baitfish. They noted that small fish are found in fresh water, brackish habitats, and shallow water along the seashore. Those from fresh water feed mostly on algae, insects, planktonic crustaceans, and foraminifera, whereas those from brackish or salt water eat crustaceans (principally copepods and amphipods), insects, mollusk larvae, algae, spiders, and annelids. Intermediate-size fish (75-150 $\mathrm{mm}$ TL) are found in deeper water at the base of exposed cliffs, large tide pools, or in rivers or ponds. They eat mainly crustacean larvae, especially the larger stages of crabs and stomatopods, but also small quantities of insects and algae. Large fish (greater than 150 $\mathrm{mm}$ TL) from surf-pounded cliffs, in the caverns of outer reefs, and other exposed localities feed mainly on crustaceans $77.6 \%$ of the stomach contents, mostly crab larvae but also stomatopod larvae and amphipods) and polychaete worms $(13.3 \%$ of the stomach contents). Tester and Takata failed to mention that this species is primarily nocturnal, at least as adults. This was pointed out by Gosline and Brock (1960:159) and Hobson (1974:948).

Tester and Takata noted that spawning takes place throughout the year, but mainly 


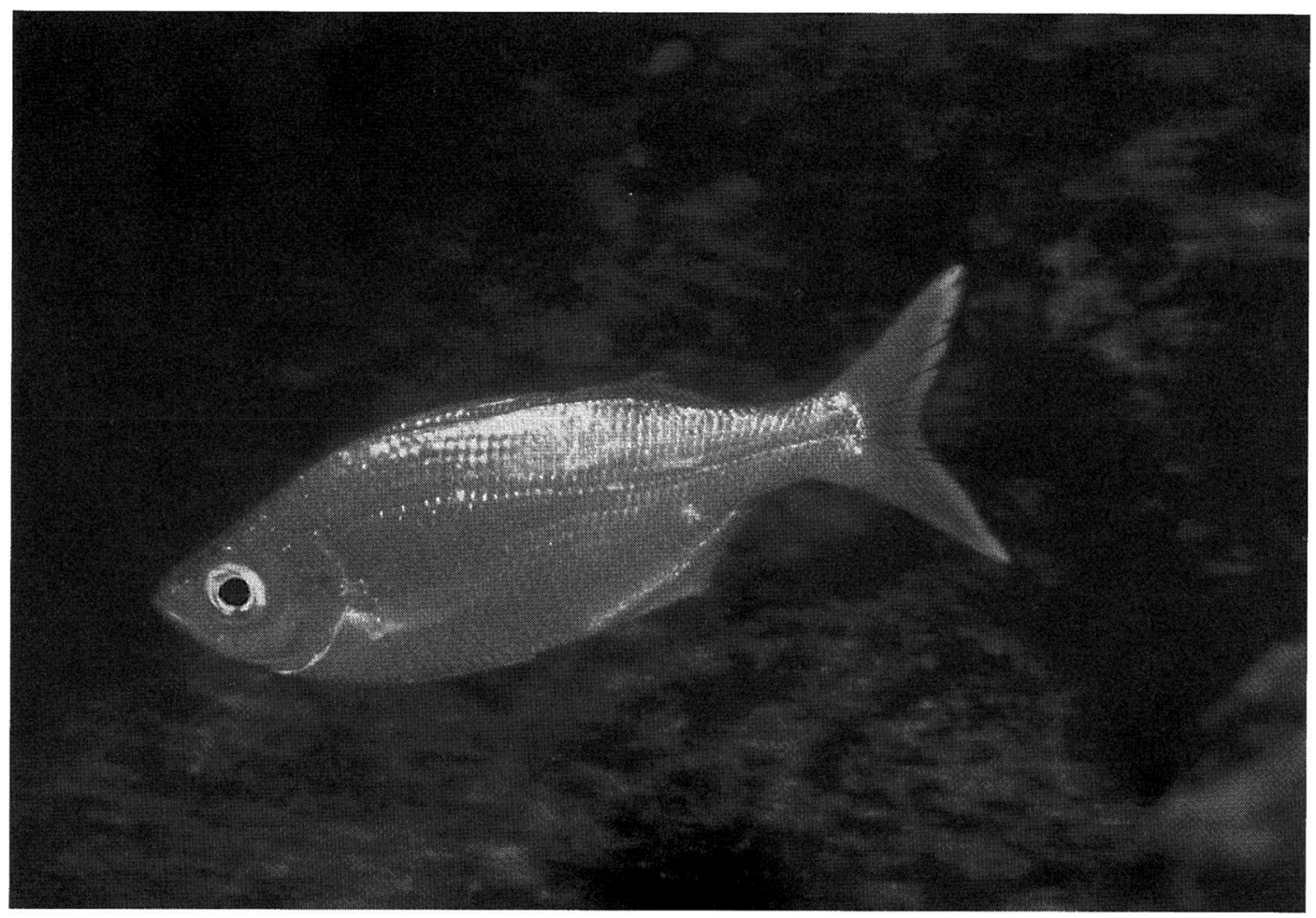

Figure 18. Kublia xenura, Maui, Hawaiian Islands.

from December to June. There is no evidence of spawning in fresh or brackish water. Young fish first appear inshore at a total length of about $25 \mathrm{~mm}$, "presumably some two months after hatching." The fish grow to about 100 $\mathrm{mm}$ by the end of the first year, and 150-175 $\mathrm{mm}$ by the end of the second. Maturity is attained at a total length of $175-200 \mathrm{~mm}$.

It should be noted, as mentioned in the Remarks for Kublia sandvicensis, that Tester and Takata were unaware that there are two species of Kublia in the Hawaiian Islands. It is clear from their statement that some small individuals had a reticular pattern on the head that $K$. sandvicensis was among their specimens for the study of $K$. xenura.

MATERIAL EXAMINED: HAWAIIAN ISLANDS, ANSP 22922, 2: 59-64 mm; CAS 212860, 3: 142-155 mm; USNM 4356, $132 \mathrm{~mm}$ (lectotype of Xenicbtbys xenurus Jordan \& Gilbert; erroneus type locality, USNM 109433, 25: 21-100 mm. Hawaici, ANSP
27991, $61 \mathrm{~mm}$; врвм 28723, 54: 32-174 mm. Maui, врвм 33458, $201 \mathrm{~mm}$. O'ahu, врвм 11533, 3: 100-121 mm; врвм 37388, $73 \mathrm{~mm}$; ВРвм 37389, $107 \mathrm{~mm}$; CAS 132013, 6: 85$130 \mathrm{~mm}$; CAS 32013, 6: 82-128 mm. Laysan, врвм 3923, 2: 155-157 mm; врвм 3924, $222 \mathrm{~mm}$; вРВм 3931, 7: 15-146 mm; вРВм 5287, 3: 80-128.5 mm. Lisiansky, врвм 3932, 5: 99-121 mm. Midway, врвм 10475, 3: 144$155 \mathrm{~mm}$; вРвм 25461, 7: 82-130 mm; вРвм 25475, 55: 38-97 mm; врвм 25516, 13: 25$103 \mathrm{~mm}$.

\section{ACKNOWLEDGMENTS}

We thank David Catania and William N. Eschmeyer of the California Academy of Sciences for the loan of specimens and help with literature; Jeff Johnson of the Queensland Museum for information on the holotype of Dules humilis; Michael W. Littmann of the Academy of Natural Sciences of Phila- 


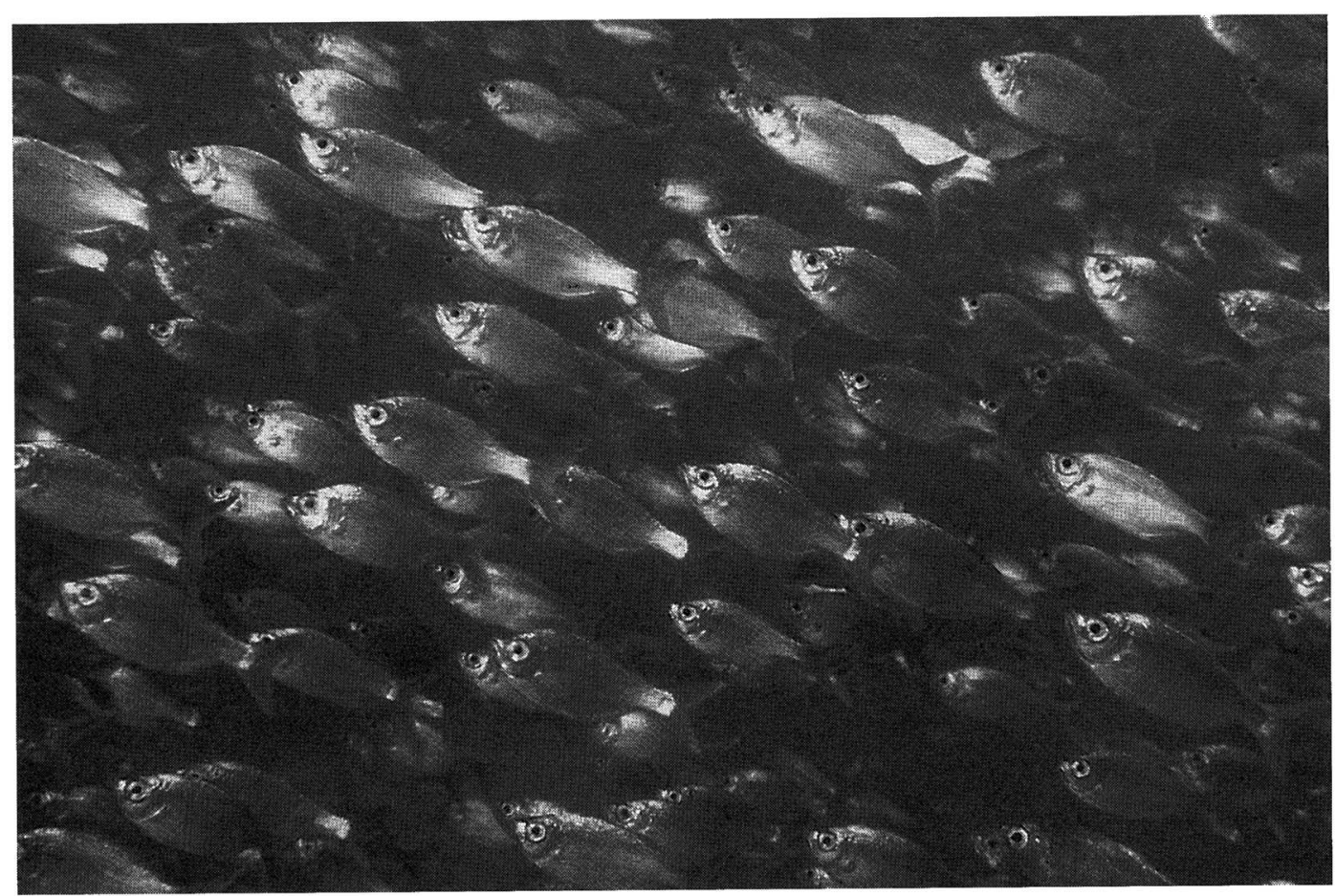

Figure 19. School of Kublia xenura, Maui, Hawaiian Islands.

delphia for data on the holotype of Kublia boninensis and the loan of specimens; Mark McGrouther and Sally Reader of the Australian Museum for the loan of the holotype of Kublia munda; Ernst Mikschi of the Naturhistorische Museum in Vienna for the information that Steindachner's syntypes of Kublia sandvicensis could not be located; Johnson Seeto of the University of the South Pacific for information on the freshwater species of Kublia in Fiji; Bernard Seret, Martine Desoutter, and Patrice Pruvost of the Muséum National d'Histoire Naturelle in Paris for data on specimens and the loan of material; David G. Smith, Jeffrey T. Williams, and Lisa Palmer of the National Museum of Natural History for information, the loan of specimens, and (from Williams) color photographs; Darrell Takaoka for alerting us to the presence of a second species of Kublia in Hawaiian waters; and Richard Winterbottom of the Royal Ontario Museum for a loan of specimens of $K$. munda from Fiji and provid- ing color photographs. Arnold Y. Suzumoto helped with curatorial matters, and Loreen R. O'Hara took radiographs.

\section{Literature Cited}

Bagnis, R., P. Mazellier, J. Bennett, and E. Christian. 1972. Poissons de Polynésie. Les Éditions du Pacifique, Papeete, Tahiti. Bennett, J. W. 1828-1830. Fishes found on the coast of Ceylon. Longman, Rees, Orme, Brown, and Green, London.

Bleeker, P. 1853. Nalezingen op de ichthyologische fauna van Bengalen en Hindostan. Verh. Bat. Gen. 25:1-164.

Bloch, M. E., and J. D. Schneider. 1801. Systema Ichthyologiae Iconibus cx Illustratum. Post obitum auctoris opus ... interpolavit. Sanderiano Commissum, Berolin.

Boulenger, G. A. 1895. Catalogue of the fishes in the British Museum, 2nd ed. Vol. 1: xix +394 . British Museum (Natural History), London. 
Bryan, W. A., and A. C. Herre. 1903. Annotated list of the Marcus Island fishes. Occas. Pap. Bernice Pauahi Bishop Mus. 2 (1): 126-139.

Cuvier, G., and A. Valenciennes. 1828. Histoire naturelle des poissons. Vol. 2: $\mathrm{xxi}+490$. F. G. Levrault, Paris.

- 1829. Histoire naturelle des poissons. Vol. 3: xxviii $+2+500$. F. G. Levrault, Paris.

1831. Histoire naturelle des poissons. Vol. 7: xxix + 531. F. G. Levrault, Paris.

Daget, J., J.-P. Gosse, and D. F. E. Thys van den Audenaerde, eds. 1986. Check-list of the freshwater fishes of Africa. CLOFFA. ISBN Bruxelles, MRAC Tervuren, ORSTOM, Paris.

De Vis, C. W. 1884. New Australian fishes in the Queensland Museum. Proc. Linn. Soc. N. S. W. 9 (2): 389-400.

Eschmeyer, W. N. 1998. Catalog of fishes. Genera of fishes, species and genera in classification, literature cited, appendices. Vol. 3. California Academy of Sciences, San Francisco.

Fowler, H. W. 1900. Contributions to the ichthyology of the tropical Pacific. Proc. Acad. Nat. Sci. Phila. 52:493-528.

—. 1907. Some new and little-known percoid fishes. Proc. Acad. Nat. Sci. Phila. 58 (1906): 510-528.

1928. The fishes of Oceania. Mem. Bernice P. Bishop Mus. 10: iii +540 .

- 1938. The fishes of the George Vanderbilt South Pacific Expedition, 1937. Monogr. Acad. Nat. Sci. Phila. 2: $\mathrm{v}+$ $349+12$.

- 1940. Zoological results of the Denison-Crockett South Pacific Expedition for the Academy of Natural Sciences of Philadelphia, 1937-1938, pt. 3-The fishes. Proc. Acad. Nat. Sci. Phila. 91:77-96. . 1944. The fishes. In Results of the Fifth George Vanderbilt Expedition (1941) (Bahamas, Caribbean Sea, Panama, Galápagos Archipelago and Mexican Pacific Islands). Monogr. Acad. Nat. Sci. Phila. 6: 57-582 + 20 pls.

- 1949. The fishes of Oceania-Supplement 3. Mem. Bernice P. Bishop Mus. 12 (2): $1-186$.
Gill, T. 1861. Synopsis of the subfamily of Percinae. Proc. Acad. Nat. Sci. Phila. 13:44-52.

. 1864. Catalogue of the fishes of Lower California in the Smithsonian Institution, collected by Mr. J. Xantus. Part IV. Proc. Acad. Nat. Sci. Phila. 15:80-88.

Gosline, W. A. 1955. The inshore fish fauna of Johnston Island, a central Pacific atoll. Pac. Sci. 9:442-480.

Gosline, W. A., and V. E. Brock. 1960. Handbook of Hawaiian fishes. University of Hawai'i Press, Honolulu.

Günther, A. C. L. G. 1873-1875. Andrew Garrett's Fische der Südsee. Vol. 1. J. Mus. Godeffroy, Fasc. 3, 6, 9: 1-128. (Reprinted 1966, J. Cramer Publisher, Lehre, Germany.)

Harry, R. R. 1953. Ichthyological field data of Raroia Atoll, Tuamotu Archipelago. Atoll Res. Bull. 18:1-190+5.

Herre, A. W. 1935. New fishes obtained by the Crane Pacific Expedition. Field Mus. Nat. Hist. Publ. Zool. Ser. 18 (12): 383438.

- 1936. Fishes of the Crane Pacific Expedition. Field Mus. Nat. Hist. Publ. Zool. Ser. 21:1-472.

Hobson, E. S. 1974. Feeding relationships of teleostean fishes on coral reefs in Kona, Hawaii. Fish. Bull. 712 (4): 915-1031.

Hombron, J. B., and H. Jacquinot. 1853. Poissons. In J. S. C. Dumont d'Urville, Voyage au Pole Sud et dans l'Océanie sur les corvettes "L'Astrolabe" et "La Zélée"; ... pendant les années 1837-1838-18391840. Vol. 3, pt. 2: 31-56.

International Code of Zoological Nomenclature, 4th ed. 2000. The International Trust for Zoological Nomenclature, c/o The Natural History Museum, London.

Jenkins, O. P. 1903. Report on collections of fishes made in the Hawaiian Islands, with descriptions of new species. Bull. U.S. Fish Comm. (1902) 22: 417-511.

Jenyns, L. 1839-1843. Fish. In C. Darwin, ed., 1842. The zoology of the voyage of $\mathrm{H}$. M. S. "Beagle," during the years 18321836. Part 4. Smith, Elder, and Co., London.

Jordan, D. S. 1912. Note on the generic name 
Safole, replacing Boulengerina, for a genus of kuhliid fishes. Proc. U.S. Natl. Mus. 42:655.

Jordan, D. S., and C. H. Bollman. 1890. Description of new species of fishes collected at the Galapagos Islands and along the coast of the United States of Colombia, 1887-1888. Proc. U.S. Natl. Mus. (1889) 12:149-183.

Jordan, D. S., and B. W. Evermann. 1896. The fishes of North and Middle America: A descriptive catalogue of the species of fish-like vertebrates found in the waters of North America, north of the Isthmus of Panama. Part 1. Bull. U.S. Natl. Mus. 47: $1 \mathrm{x}+1240$.

- 1905. The aquatic resources of the Hawaiian Islands. Part I.-The shore fishes of the Hawaiian Islands, with a general account of the fish fauna. Bull. U.S. Fish Comm. (1903) 23: xxviii $+574+73$.

Jordan, D. S., and C. H. Gilbert. 1882. Description of a new species of Xenichtbys ( $X$. xenurus) from the west coast of Central America. Proc. U.S. Natl. Mus. (1881) 4:454.

Jordan, D. S., and E. K. Jordan. 1922. A list of the fishes of Hawaii, with notes and descriptions of new species. Mem. Carnegie Mus. 10 (1): 1-92.

Jordan, D. S., and A. Seale. 1906. The fishes of Samoa. Description of the species found in the archipelago, with a provisional check-list of the fishes of Oceania. Bull. Bur. Fish. (1905) 25:173-488.

Kendall, W. C., and E. L. Goldsborough. 1911. Reports on the scientific results of the expedition to the tropical Pacific in charge of Alexander Agassiz, by the U. S. Fish Commission Steamer "Albatross," from August, 1899, to March, 1900, Commander Jefferson F. Moser, U. S. N., commanding. XIII. The shore fishes. Mem. Mus. Comp. Zool. 26 (7): 241-343.

Kendall, W. C., and L. Radcliffe. 1912. Reports on the scientific results of the expedition to the tropical Pacific in charge of Alexander Agassiz, by the U. S. Fish Commission Steamer "Albatross," from October, 1904, to March, 1905, Lieut. Commander L. M. Garrett, U. S. N., commanding. XXV. The shore fishes. Mem. Mus. Comp. Zool. 35 (3): 77-171.

Lacépède, B. G. E. 1802. Histoire naturelle des poissons. Vol. 4: xliv +728 pp. Chez Plassan, Paris.

Lesson, R. P. 1830-1831. Poissons. Pages 66-238 in L. I. Duperrey, Voyage autour du monde, ..., sur la corvette ... Coquille, pendant les années 1822, 1823, 1824, et 1825 ..., Zoologie. Vol. 2, pt. 1.

Liénard, E. 1832. Untitled presentation in $M$. J. Desjardin, Analyse des travaux de la Société d'Histoire Naturelle de l'ile Maurice, pendant la 2nd Année. Proc. Zool. Soc. Lond. 1832 (1): 111-112.

Macleay, W. 1881. Descriptive catalogue of the fishes of Australia. Part I. Proc. Linn. Soc. N. S. W. 5 (3): 302-444.

- 1884. Contribution to a knowledge of the fishes of New Guinea, no. 4. Proc. Linn. Soc. N. S. W. (1883) 8:252281.

Masuda, H., K. Amaoka, C. Araga, T. Uyeno, and T. Yoshino, eds. 1984. The fishes of the Japanese Archipelago. Tokai University Press, Tokyo.

McCulloch, A. R. 1929-1930. A check-list of the fishes recorded from Australia. Aust. Mus. Syd. Mem. 5: x +534.

Ogilby, J. D. 1897. A contribution to the zoology of New Caledonia. Proc. Linn. Soc. N. S. W. (1897) 23:762-770.

Paxton, J. R., D. F. Hoese, G. R. Allen, and J. E. Hanley. 1989. Zoological catalogue of Australia. Vol. 7. Pisces, Petromyzontidae to Carangidae. Australian Government Publishing Service, Canberra.

Randall, J. E. 1955. Fishes of the Gilbert Islands. Atoll Res. Bull. 47: xi +243.

1960. New fishes for Hawaii. Sea Frontiers 6 (1): 33-43.

- -1973 . Tahitian fish names and a preliminary checklist of the fishes of the Society Islands. Occas. Pap. Bernice Pauahi Bishop Mus. 24 (11): 167-214.

. 1985. Guide to Hawaiian reef fishes. Harrowood Books, Newtown Square, Pennsylvania.

Randall, J. E. 1999. Report on fish collections from the Pitcairn Islands. Atoll Res. Bull. 461:1-36. 
Randall, J. E., and E. A. Lachner. 1986. The status of the Indo-West Pacific cardinalfishes Apogon aroubiensis and S. nigrofasciatus. Proc. Biol. Soc. Wash. 99 (1): 110-120.

Regan, C. T. 1913. A revision of the fishes of the genus Kublia. Proc. Zool. Soc. Lond. 1913 (2): 374-381.

Ryan, P. A. 1980. A checklist of the brackish and freshwater fish of Fiji. South Pac. J. Nat. Sci. 1:58-73.

Schultz, L. P. 1943. Fishes of the Phoenix and Samoan Islands collected in 1939 during the expedition of the U. S. S. "Bushnell." Bull. U.S. Natl. Mus. 180: $x+316$.

Schultz, L. P., and Collaborators. 1953. Fishes of the Marshall and Marianas Islands. Bull. U.S. Natl. Mus. 202, vol. 1: $\mathrm{xxxii}+685$.

Scudder, S. H. 1882. Nomenclator Zoologicus. An alphabetical list of all generic names that have been employed by naturalists for recent and fossil animals from the earliest times to the close of the year 1879. Bull. U.S. Natl. Mus. 19: xix $+1-$ 376 (part 1) and 1-340 (part 2).

Seale, A. 1906. Fishes of the South Pacific. Occas. Pap. Bernice Pauahi Bishop Mus. 4 (1): $1-89$.

Smith, M. M., and P. C. Heemstra. 1986. Smiths' sea fishes. Macmillan South Africa, Johannesburg.
Smith, R., and J. Swain. 1883. Notes on a collection of fishes from Johnston's Island (700 miles S. W. of the Hawaiian group) including descriptions of five new species. Proc. U.S. Natl. Mus. (1882) 5:119-143.

Snyder, J. O. 1904. A catalogue of the shore fishes collected by the steamer Albatross about the Hawaiian Islands in 1902. Bull. U.S. Fish Comm. (1902) 22:513-538.

Steindachner, F. 1876. Ichthyologische Beiträge (V). Sitzungsber. Akad. Wiss. Wien 74 (pt. 1): 49-240.

- 1887. Ichthyologische Beiträge (XIV). Anz. Akad. Wiss. Wien 24 (19): 230-231. 1898. Uber eine neue Kuhlia-Art aus dem Golfe von Akabah. Sitzungsber. Akad. Wiss. Wien 107 (pt. 1): 461-464. 1901. Fische aus dem Stillen Ocean Erbebnisse einer Reise nach dem Pacific (Schauinsland 1896-97). Denkschr. Akad. Wiss. Wien 70:483-521.

Tester, A. L., and M. Takata. 1953. Contribution to the biology of the aholehole a potential baitfish. Final Report, IRAC grant no. 29. Hawaii Mar. Lab. Contrib. 38: iii +54 .

Van der Elst, R. 1981. A guide to the common sea fishes of southern Africa. C. Struik, Cape Town. 